\title{
Revealing the Potential Application of EC-Synthetic Retinoid Analogues in Anticancer Therapy
}

\author{
Mohamed R. Abdelaal ${ }^{1,2}\left(\mathbb{D}\right.$, Sameh H. Soror ${ }^{1,2}\left(\mathbb{D}\right.$, Mohamed R. Elnagar ${ }^{3}(\mathbb{D})$ and Hesham Haffez $^{1,2, *(D)}$ \\ 1 Biochemistry and Molecular Biology Department, Faculty of Pharmacy, Helwan University, \\ Cairo 11795, Egypt; mohamed_abdelaal@pharm.helwan.edu.eg (M.R.A.); \\ sameh_soror@pharm.helwan.edu.eg (S.H.S.) \\ 2 Center of Scientific Excellence "Helwan Structural Biology Research, (HSBR)", Helwan University, \\ Cairo 11795, Egypt \\ 3 Department of Pharmacology and Toxicology, Faculty of Pharmacy, Al-Azhar University, Cairo 11823, Egypt; \\ mohamed.r.elnagar@azhar.edu.eg \\ * Correspondence: hesham.haffez@pharm.helwan.edu.eg; Tel.: +20-1094970173
}

check for updates

Citation: Abdelaal, M.R.; Soror, S.H.; Elnagar, M.R.; Haffez, H. Revealing the Potential Application of EC-Synthetic Retinoid Analogues in Anticancer Therapy. Molecules 2021, 26, 506. https://doi.org/10.3390/ molecules26020506

Academic Editor: María

Ángeles Castro

Received: 11 December 2020

Accepted: 8 January 2021

Published: 19 January 2021

Publisher's Note: MDPI stays neutral with regard to jurisdictional clai$\mathrm{ms}$ in published maps and institutional affiliations.

Copyright: (C) 2021 by the authors. Licensee MDPI, Basel, Switzerland. This article is an open access article distributed under the terms and conditions of the Creative Commons Attribution (CC BY) license (https:// creativecommons.org/licenses/by/ $4.0 /)$.

\begin{abstract}
Background and Aim: All-trans retinoic acid (ATRA) induces differentiation and inhibits growth of many cancer cells. However, resistance develops rapidly prompting the urgent need for new synthetic and potent derivatives. EC19 and EC23 are two synthetic retinoids with potent stem cell neuro-differentiation activity. Here, these compounds were screened for their in vitro antiproliferative and cytotoxic activity using an array of different cancer cell lines. (2) Methods: MTT (3-(4,5-dimethylthiazol-2-yl)-2,5-diphenyltetrazolium bromide) assay, AV/PI (annexin V-fluorescein isothiocyanate (FITC)/propidium iodide (PI)), cell cycle analysis, immunocytochemistry, gene expression analysis, Western blotting, measurement of glutamate and total antioxidant concentrations were recruited. (3) Results: HepG2, Caco-2, and MCF-7 were the most sensitive cell lines; HepG2 (ATRA; 36.2, EC19; 42.2 and EC23; $0.74 \mu \mathrm{M}$ ), Caco-2 (ATRA; 58.0, EC19; 10.8 and EC23; $14.7 \mu \mathrm{M}$ ) and MCF-7 (ATRA; 99.0, EC19; 9.4 and EC23; $5.56 \mu \mathrm{M}$ ). Caco-2 cells were selected for further biochemical investigations. Isobologram analysis revealed the combined synergistic effects with 5-fluorouracil with substantial reduction in $\mathrm{IC}_{50}$. All retinoids induced apoptosis but EC19 had higher potency, with significant cell cycle arrest at $\mathrm{subG}_{0}-\mathrm{G}_{1},-\mathrm{S}$ and $\mathrm{G}_{2} / \mathrm{M}$ phases, than ATRA and EC23. Moreover, EC19 reduced cellular metastasis in a transwell invasion assay due to overexpression of E-cadherin, retinoic acid-induced 2 (RAI2) and Werner (WRN) genes. (4) Conclusion: The present study suggests that EC-synthetic retinoids, particularly EC19, can be effective, alone or in combinations, for potential anticancer activity to colorectal cancer. Further in vivo studies are recommended to pave the way for clinical applications.
\end{abstract}

Keywords: anticancer; apoptosis; Caco-2; EC19; EC23; metastasis; retinoic-acid receptors

\section{Introduction}

Retinoids are naturally occurring structural and functional analogues of vitamin A that play a vital role in mammalian physiology during infancy and adulthood [1]. They influence many intracellular pathways by activating a number of trans-acting, DNAbinding receptors. This family of nuclear receptors includes retinoic acid receptors (RARs) and retinoid $X$ receptors (RXRs). Each receptor has 3 isotypes: $R A(X) R \alpha, R A(X) R \beta$ and $\mathrm{RA}(\mathrm{X}) \mathrm{R} \gamma$ [2]. Alternative splicing and differential promoter activation generate several isoforms from each isotype [3]. RARs are naturally targeted by all-trans-retinoic acid (ATRA), the main intracellular metabolite of vitamin A [4]. However, other natural analogues such as 9-cis-RA and 13-cis-RA mainly activate RXRs [5]. Retinoids are important for diverse biological processes such as embryonic morphogenesis, cell growth, and hematopoiesis in vitro and in vivo [6]. Also, retinoic acid (RA) has a protective action on the epithelium 
through preventing ultraviolet-induced damage to the skin following exposure to ultraviolet radiation [7]. On the cellular level, retinoids are involved in diverse biological activities such as cellular growth and cohesion in stem cells [8], immunomodulatory effects [9] and growth inhibition particularly in cancer cells $[10,11]$. Standard chemotherapeutic treatments against cancer are necessary for surgery inappropriate patients and after surgical resection to improve prospects for survival and surgery outcomes [12]. However, the issue of multidrug resistance (MDR) is a major obstacle to obtain the desired results [13], making the discovery of novel tumor inhibitors necessary for effective therapeutic strategies that help solving the problem. However, this process is durable, costly and most of these new drugs fail in the clinic because of undesired side effects and toxicity [14]. As a result, there is an urgent need for repurposing effective synthetic derivatives to alleviate the emerging resistance and provide higher stability under different treatment environments. In the last few decades, retinoids attracted great attention as promising drugs for cancer prevention and treatment [15]. ATRA has been clinically tested in acute promyelocytic leukemia [16,17], prostate cancer [18,19], and other types of cancer [20]. However, ATRA resistance rapidly emerged after starting the treatment [18,21]. Moreover, it undergoes photoisomerization and degradation in solution into a mixture of retinoic acid isomers [22,23] with different mechanisms of action [24,25]. This may lead to inconsistency with ATRA dosing in clinical settings.

Therefore, on the scaffold of ATRA, two chemical derivatives called EC-synthetic retinoids have been synthesized by Whiting's group. The para-isomer,4-(5,5,8,8-tetramethyl5,6,7,8-tetrahydronaphthalen-2-ylethynyl) benzoic acid, is often called EC23 while the metaisomer,3-(5,5,8,8-tetramethyl-5,6,7,8-tetrahydronaphthalen-2-ylethynyl) benzoic acid, is called EC19 (Figure 1) [26]. The two analogues showed higher physicochemical stability for extended periods under the laboratory environment [26]. Additionally, intensive research on cellular [27], biochemical [28] and molecular levels [28] was performed at different time scales to probe the relationship between the structures and functions of EC23 and EC19. In vivo results showed that EC23 induces increased maturation and stabilization of the axonal cytoskeleton [29] and developing limb bud [30]. In vitro data support the previous observation that EC23 is a potent inducer of pluripotent stem cell differentiation (TERA2.cl.SP12) and neuroblastoma (SHSY5Y) with the same mechanism as ATRA [27,28].

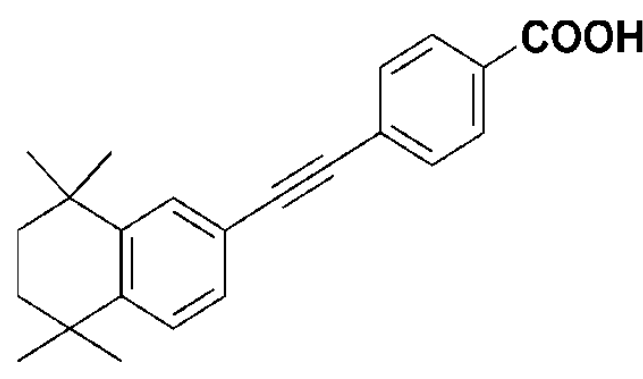

EC23

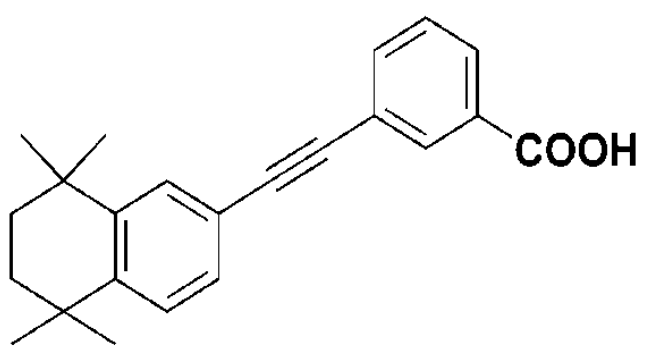

EC19

Figure 1. Structures of EC-synthetic retinoic acid analogues [26].

Although intensive research work was done by our research group on EC-synthetic analogues for their potential application in neuroscience as inducers of neuro-differentiation, there is no prior information about the efficiency of these analogues compared to ATRA for potential growth inhibition in cancer. This may be a good approach to aid ligand design and for repurposing of EC-synthetic retinoids as anticancer ligands benefitting from their activity on cell differentiation. Therefore, we seek to determine their antiproliferative potency through RARs and other pathways such as apoptosis, drug resistance and cell metastasis, and thus understand determinants responsible for the biological potency of these tested retinoids. 


\section{Results}

\subsection{EC19 and EC23 Induce Cell Death In Vitro}

The antiproliferative effect of EC19 and EC23, compared to ATRA as a positive control retinoid, was assessed on cultured cancer cells using the MTT assay. As shown in (Figure S1), different sigmoidal curves were constructed for each specific cell line with retinoids for calculation of $\mathrm{IC}_{50}$. The dynamic dose concentrations were chosen to cover the bend points of the sigmoidal curves and cover the expected change in $\mathrm{IC}_{50}$ values. $\mathrm{A}$ constant dilution factor of $10 \times$ was chosen to minimize the variability with logarithmic scale dilution change, as previously documented [31,32]. The magnitude of reduction in cell growth was dose-dependent and varied for each retinoid molecule markedly among different cell lines, in comparison to ATRA and negative controls. Table 1 shows the different $\mathrm{IC}_{50}$ values for EC-synthetic analogues in comparison to ATRA. For hepatocellular carcinoma cell lines, HepG2 showed high sensitivity to retinoids at $\mathrm{IC}_{50}$ doses lower than $100 \mu \mathrm{M}$ compared to Huh7 cells. EC23 showed the lowest IC $\mathrm{I}_{50}$ in HepG2 cells $(0.74 \pm 0.001 \mu \mathrm{M})$ compared to EC19 and ATRA (IC 50 values; $42.2 \pm 0.92$ and $36.2 \pm 1.9 \mu \mathrm{M}$, respectively). For colorectal carcinoma (CRC), Caco-2 was the most sensitive cell line to different retinoids with the highest antiproliferation potency for EC19 $\left(\mathrm{IC}_{50} ; 10.8 \pm 0.1 \mu \mathrm{M}\right)$, followed by EC23 $\left(\mathrm{IC}_{50} ; 14.7 \pm 0.73 \mu \mathrm{M}\right)$ compared to ATRA $\left(\mathrm{IC}_{50} ; 58.0 \pm 1.0 \mu \mathrm{M}\right)$. HCT-116 and HT29 exhibited variable sensitivity to tested retinoids with only EC23 potent in HCT-116 $\left(\mathrm{IC}_{50} ; 44.46 \pm 1.1 \mu \mathrm{M}\right)$ and ATRA potent in HT-29 $\left(\mathrm{IC}_{50} ; 0.002 \pm 0.01 \mu \mathrm{M}\right)$. For breast cancer cells, MCF-7 was the most sensitive cell line to retinoids where EC23 was the most potent antiproliferative compound $\left(\mathrm{IC}_{50} ; 5.56 \pm 0.01 \mu \mathrm{M}\right)$, followed by $\mathrm{EC} 19$ ( $\mathrm{IC}_{50}$; $9.4 \pm 0.13 \mu \mathrm{M})$ and ATRA $\left(\mathrm{IC}_{50} ; 99 \pm 0.26 \mu \mathrm{M}\right)$. MDA-MB 231 was resistant to all retinoids with $\mathrm{IC}_{50}>100 \mu \mathrm{M}$. For prostate and lung cancers, DU145 was the only cell line sensitive to $\mathrm{EC} 19\left(\mathrm{IC}_{50} ; 86.9 \pm 2.0 \mu \mathrm{M}\right)$ while A549 was sensitive only to ATRA $\left(\mathrm{IC}_{50} ; 84.7 \pm 3.2 \mu \mathrm{M}\right)$. WI-38 and Vero cell lines were recruited for screening the cytotoxicity of these retinoids against normal cells. EC23 showed the most cytotoxic effect to both normal cell lines (WI-38; $\mathrm{IC}_{50}=8.01 \pm 0.13$ and Vero; $\left.\mathrm{IC}_{50}=35.23 \pm 1.02 \mu \mathrm{M}\right)$. EC19 and ATRA showed no cytotoxicity to Vero cells and moderate cytotoxicity to WI-38 (IC 50 values; $48.4 \pm 1.2$ and $34.0 \pm 1.1 \mu \mathrm{M}$, respectively). Therefore, WI-38 was selected as the normal cell line model of human origin to assess the selectivity and cytotoxicity of the tested retinoids compared with other cancer cell lines. Data shown in Table 1 demonstrate that EC19 had selectivity index (SI) $>1$ for three cancer cell lines (HepG2, Caco-2 and MCF-7). EC23 had SI > 1 for two cancer cell lines (HepG2 and MCF-7). ATRA was shown to have SI $>1$ against only one cancer cell line (MCF-7). It is well known from the literature that anticancer agents with greater SI value (specifically when SI $>1$ ) are more selective and safer for future in vivo studies [33-35]. The SI data shown in Table 1 indicate that EC19 and EC23 have a relatively safe effect on Caco-2 and HepG2, respectively. Therefore, due to the comparable $\mathrm{IC}_{50}$ of EC19 and EC23 to the Caco-2 cell line versus ATRA, this cell line will be selected for further biochemical and mechanistic investigations to understand their potency and mechanism of antiproliferative activity.

\subsection{Synergistic Effect of Retinoids and 5-Fluorouracil (5-FU) in Caco-2 Cells}

The effect of the combined administration of ATRA, EC19 or EC23 with the standard genotoxic agent, 5-fluorouracil (5-FU), was assessed on the Caco-2 cell line using isobologram analysis. First, the non-linear regression model, fitted from MTT assay data, revealed that single treatment with 5-FU yields an $\mathrm{IC}_{50}$ value of $18.4 \pm 0.6 \mu \mathrm{M}$. Next, $\mathrm{IC}_{50}$ values of ATRA, EC19 and EC23 were combined with $\mathrm{IC}_{50}$ of 5-FU (with fixed ratios) onto the cells and an exaggerated response was observed. Table 2 and Figure 2 show the combined $\mathrm{IC}_{50}$ values for the mixture containing ATRA, EC19 or EC23, plus 5-FU as $8.7 \pm 0.9,2.47 \pm 0.33$, and $2 \pm 0.22 \mu \mathrm{M}$, respectively. Table 2 shows the combination indices $(\mathrm{CI})$ for the mixtures of ATRA, EC19 and EC23 with 5-FU as $0.29 \pm 0.03,0.46 \pm 0.06$ and $0.27 \pm 0.03$, respectively. Moreover, the significant reduction in $\mathrm{IC}_{50}$ was reflected in high dose reduction index (DRI) values (ranging from 4.5 to 7.5 ), highlighting the strong reduction in doses needed to 
achieve the same level of cytotoxicity (Table 2). These results suggest that an augmentation in the anticancer potency of the standard chemotherapeutic agent, 5-FU, can be induced by the combination with the EC-synthetic retinoids in Caco-2 cells. In addition, the $\mathrm{IC}_{50}$ doses required for the induction of growth inhibition were reduced by fractions of $\mathrm{IC}_{50}$ $\left(\times \mathrm{IC}_{50}\right)$ to minimize the cytotoxicity effect that may occur at high doses in non-cancerous neighboring cells.

Table 1. The In Vitro antiproliferative activity of all-trans-retinoic acid (ATRA), EC19 and EC23 against different cancerous cell lines. WI-38 was selected as a normal cell line from human origin for the calculation of SI (selectivity index). SI was calculated as $\mathrm{IC}_{50}$ retinoid (WI-38)/ $\mathrm{IC}_{50}$ retinoid (cancer cell line). Data represent mean \pm standard error of the mean (SEM), $n=3$.

\begin{tabular}{|c|c|c|c|c|c|c|}
\hline \multirow{3}{*}{ Cell Line } & \multicolumn{6}{|c|}{${ }^{*} \mathrm{IC}_{50}(\mu \mathrm{M}) \pm \mathrm{SEM}$ and Corresponding SI } \\
\hline & \multicolumn{2}{|c|}{ ATRA } & \multicolumn{2}{|c|}{ EC19 } & \multicolumn{2}{|c|}{ EC23 } \\
\hline & $\mathrm{IC}_{50}$ & SI & $\mathrm{IC}_{50}$ & SI & $\mathrm{IC}_{50}$ & SI \\
\hline WI-38 & $34.0 \pm 1.1$ & 1 & $48.4 \pm 1.2$ & 1 & $8.01 \pm 0.13$ & 1 \\
\hline Vero & $>100$ & 1 & $>100$ & 1 & $35.23 \pm 1.02$ & 1 \\
\hline HepG2 & $36.2 \pm 1.9$ & $0.94 \pm 0.02$ & $42.2 \pm 0.92$ & $1.2 \pm 0.002$ & $0.74 \pm 0.001$ & $10.82 \pm 1.0$ \\
\hline Huh7 & $>100$ & $<1$ & $>100$ & $0.14 \pm 0.01$ & $>100$ & $0.02 \pm 0.001$ \\
\hline Caco-2 & $58.0 \pm 1.0$ & $0.59 \pm 0.01$ & $10.8 \pm 0.1$ & $4.5 \pm 0.01$ & $14.7 \pm 0.73$ & $0.54 \pm 0.01$ \\
\hline HCT-116 & $>100$ & $<1$ & $>100$ & $<1$ & $44.46 \pm 1.1$ & $0.18 \pm 0.003$ \\
\hline HT-29 & $0.002 \pm 0.01$ & $>1$ & $>100$ & $<1$ & $>100$ & $<1$ \\
\hline MCF-7 & $99 \pm 0.26$ & $0.34 \pm 0.01$ & $9.4 \pm 0.13$ & $5.18 \pm 0.1$ & $5.56 \pm 0.01$ & $1.44 \pm 0.004$ \\
\hline MDA-MB 231 & $>100$ & $<1$ & $>100$ & $<1$ & $>100$ & $<1$ \\
\hline DU-145 & $>100$ & $<1$ & $86.9 \pm 2.0$ & $0.56 \pm 0.001$ & $>100$ & $<1$ \\
\hline PC3 & $>100$ & $<1$ & $>100$ & $<1$ & $>100$ & $<1$ \\
\hline A549 & $84.7 \pm 3.2$ & $0.4 \pm 0.01$ & $>100$ & $<1$ & $>100$ & $<1$ \\
\hline
\end{tabular}

${ }^{*} \mathrm{IC}_{50}$ values were determined by non-linear regression of dose-response using the 4-parameter logistic model (4PL) in GraphPad prism 7.

Table 2. Isobologram analysis of the combinations of individual retinoids and 5-fluorouracil (5-FU) (using fixed ratios of the individual $\mathrm{IC}_{50}$ values) in Caco-2 cells. A synergistic effect was observed with the combination strategy. Dose reduction index (DRI) and combination index (CI) confirm the synergistic effect. Data represent mean $\pm \mathrm{SEM}, n=3$.

\begin{tabular}{|c|c|c|c|c|c|c|}
\hline \multirow{2}{*}{ Drug } & \multirow{2}{*}{$\mathrm{IC}_{50}(\mu \mathrm{M})$} & \multirow{2}{*}{$\begin{array}{c}\times \mathrm{IC}_{50}(\mu \mathrm{M}) \\
\text { (Combination) with 5-FU }\end{array}$} & \multicolumn{2}{|c|}{ Individual $\mathrm{IC}_{50}(\mu \mathrm{M})$ (Combination) } & \multirow{2}{*}{ DRI } & \multirow{2}{*}{ CI } \\
\hline & & & 5-FU & Retinoid & & \\
\hline 5-FU & $18.4 \pm 0.6$ & & 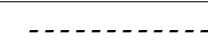 & $-\ldots$ & & \\
\hline ATRA & $58 \pm 1.0$ & $0.15 \pm 0.01$ & $2.8 \pm 0.3$ & $8.7 \pm 0.9$ & $6.9 \pm 0.7$ & $0.29 \pm 0.03^{* *}$ \\
\hline EC19 & $10.8 \pm 0.1$ & $0.229 \pm 0.03$ & $4.21 \pm 0.6$ & $2.47 \pm 0.3$ & $4.5 \pm 0.6$ & $0.46 \pm 0.06^{* *}$ \\
\hline EC23 & $14.7 \pm 0.7$ & $0.136 \pm 0.02$ & $2.5 \pm 0.3$ & $2 \pm 0.2$ & $7.5 \pm 0.8$ & $0.27 \pm 0.03^{* *}$ \\
\hline
\end{tabular}

** $p<0.01$; where $p$ values indicate the level of significance compared to $\mathrm{CI}=1.0$.

\subsection{Apoptotic Effects of Retinoids in Caco-2 Cells}

Propidium iodide (PI) is commonly used in conjunction with Annexin-V to discriminate viable cells from those undergoing early or late apoptosis, or necrosis [36]. The annexin V-fluorescein isothiocyanate (FITC)/PI staining (AV/PI) showed Caco-2 cell distribution within the four different quadrants $\left(\mathrm{C}^{--}, \mathrm{C}^{-+}, \mathrm{C}^{+-}, \mathrm{C}^{++}\right)$of the 2D plot. In the untreated cells (negative control), there was minimal cell distribution in $\mathrm{C}^{-+}, \mathrm{C}^{+-}, \mathrm{C}^{++}$indicating a very low number of necrotic, early, and late apoptotic cells, respectively. Treatment of Caco- 2 cells with the $\mathrm{IC}_{50}$ concentration of retinoids for 12 and $24 \mathrm{~h}$ showed variable apoptotic effects on Caco-2 cells. 


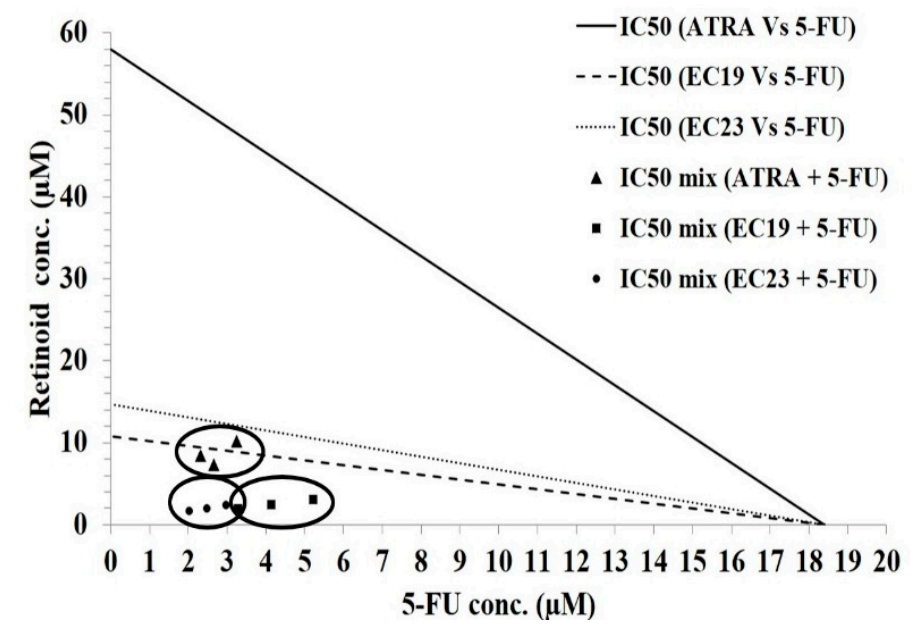

Figure 2. Isobologram analysis applied to Caco-2 cells co-treated with 5-FU in addition to ATRA, EC19, or EC23 for $24 \mathrm{~h}$. The antagonistic (upper), the synergistic (lower), and the additivity (on the line) regions are shown. The analysis indicates synergism at the $\mathrm{IC}_{50}$ level. Data points in circles represent the mean of 3 independent replicates.

After $12 \mathrm{~h}$ of treatment, the percentage of viable cells increased with EC19 and EC23 compared to ATRA and negative control (93.65 \pm 14.0 and $91.61 \pm 13.7$, respectively, compared to ATRA; $87.99 \pm 15.0$ and negative control; $80.30 \pm 7.9$ ). Also, there was no significant effect on any of the other apoptotic phases. After $24 \mathrm{~h}$ of treatment, there was a significant reduction in the percentage of viable cells with higher potency for EC19 followed by EC23 and ATRA $(24.5 \pm 11.8,34.4 \pm 18.3$ and $52.4 \pm 11.5$, respectively). Moreover, there was a significant increase in the percentage of early apoptotic cells with the same order of potency as previously mentioned (EC19; $75.3 \pm 13.8$, EC23; $65.4 \pm 18.4$ and ATRA; $47.4 \pm 2.5$ ) (Table 3). In addition, the significant induction of apoptosis after $24 \mathrm{~h}$ was confirmed through the calculation of apoptotic index (AI) which was significantly higher for EC23 and EC19 followed by ATRA compared to the negative control $(89,84$ and 63 compared to control; 18). There was no increase in AI after $12 \mathrm{~h}$ of treatment.

Table 3. The percentage of viable, apoptotic, late apoptotic, and necrotic cells was measured by AV/PI assay using flow cytometry. The assay was performed after the treatment of Caco-2 cells for 12 or $24 \mathrm{~h}$ with ATRA, EC19 and EC23 compared to $0.1 \%$ DMSO negative control. The apoptotic index was calculated as the percentage of the apoptotic cells to the total number of gated cells. Data represent mean \pm standard error of the mean (SEM), $n=3$.

\begin{tabular}{|c|c|c|c|c|c|c|c|c|}
\hline \multirow{2}{*}{$\begin{array}{l}\text { Apoptosis Analysis of } \\
\text { Caco-2 Cell Line }\end{array}$} & \multicolumn{4}{|c|}{$12 \mathrm{~h}$ Treatment } & \multicolumn{4}{|c|}{$24 \mathrm{~h}$ Treatment } \\
\hline & Control & ATRA & EC19 & EC23 & Control & ATRA & EC19 & EC23 \\
\hline$\%$ viable cells $\left(\mathrm{C}^{--}\right)$ & $80.30 \pm 7.9$ & $87.99 \pm 15.0$ & $93.65 \pm 14.0$ & $91.61 \pm 13.7$ & $78.83 \pm 6.4$ & $52.4 \pm 11.5^{*}$ & $24.5 \pm 11.8^{* * *}$ & $34.4 \pm 18.3^{* * *}$ \\
\hline$\%$ early apoptotic cells $\left(\mathrm{C}^{+-}\right)$ & $19.61 \pm 5.5$ & $11.99 \pm 1.9$ & $6.30 \pm 1.1$ & $8.34 \pm 1.1$ & $20.20 \pm 2.8$ & $47.4 \pm 2.5 * *$ & $75.3 \pm 13.8 * * *$ & $65.4 \pm 18.4^{* * *}$ \\
\hline$\%$ late apoptotic cells $\left(\mathrm{C}^{-+}\right)$ & 0.00 & 0.00 & 0.01 & 0.01 & 0.0 & 0.0 & 0.0 & 0.0 \\
\hline$\%$ necrotic cells $\left(\mathrm{C}^{++}\right)$ & 0.08 & 0.01 & $0.4 \pm 0.1$ & 0.05 & $0.95 \pm 0.18$ & $0.28 \pm 0.17$ & $0.18 \pm 0.05$ & $0.16 \pm 0.14$ \\
\hline$\%$ Apoptotic index (AI) & 20 & 12 & 6.3 & 8.3 & 18 & 63 & 84 & 89 \\
\hline
\end{tabular}

${ }^{*} p<0.05,{ }^{* *} p<0.01$ and ${ }^{* * *} p<0.001 . p$ Values indicate the significance in comparison to untreated control cells.

\subsection{Synthetic Retinoids Induce Cell Cycle Arrest and Reduce Cellular Proliferation}

Cell cycle analysis was used for the assessment of DNA content in Caco-2 cells after treatment with retinoids for both 12 and $24 \mathrm{~h}$. The percentage of treated cells in all cell cycle phases $\left(\mathrm{G}_{0}-\mathrm{G}_{1}, \mathrm{~S}\right.$ and $\left.\mathrm{G}_{2} / \mathrm{M}\right)$ is presented in Table 4 . After $12 \mathrm{~h}$ of treatment, ATRA and EC19 were able to slightly induce the accumulation of dividing cells in both S- (57.5 \pm 8.1 and $51.5 \pm 7.2$, respectively) and $\mathrm{G}_{2} / \mathrm{M}(16.3 \pm 1.9$ and $9.1 \pm 1.3$, respectively) phases compared to control cells. EC23 was able to slightly induce the accumulation of cells at the $\mathrm{G} 2 / \mathrm{M}$ phase only $(6.8 \pm 0.8)$ compared to control. After $24 \mathrm{~h}$ of treatment, ATRA was able to induce cell cycle arrest and accumulation of cells at subG $\mathrm{G}_{0}-\mathrm{G}_{1}$ and $\mathrm{G}_{2} / \mathrm{M}$ phases 
(1.6 \pm 0.19 and $31.8 \pm 4.8$, respectively). EC19 and EC23 were able to induce cell cycle arrest at three different levels including subG $\mathrm{G}_{0}-\mathrm{G}_{1}, \mathrm{~S}-$ and $\mathrm{G}_{2} / \mathrm{M}$ phases as shown in Table 4; the $\% \mathrm{G}_{2} \mathrm{M} / \mathrm{G}_{0}-\mathrm{G}_{1}$ ratio was elevated for all three retinoids after 24-h treatment compared to that of the negative control. Overlaying the different histograms in Figure 3 of the control (yellow color) with that of the different retinoids showed the regions of the cell cycle arrest and confirmed the retrieved data.

Table 4. Cell cycle analysis of Caco-2 cells after ATRA, EC19 and EC23 treatment for 12 and 24 h showing the DNA content at different cycle phases. $\% \mathrm{G}_{2} \mathrm{M} / \mathrm{G}_{0}-\mathrm{G}_{1}$ ratio was calculated as the percentage of the dividing cells in the mitotic phase to the growing cells in the $\mathrm{G}_{0}-\mathrm{G}_{1}$ phase.

\begin{tabular}{|c|c|c|c|c|c|c|c|}
\hline \multirow{2}{*}{$\begin{array}{l}\text { Cell Cycle Analysis of } \\
\text { Caco-2 Cell Line }\end{array}$} & \multirow{2}{*}{ Control } & \multicolumn{3}{|c|}{$12 \mathrm{~h}$ Treatment } & \multicolumn{3}{|c|}{$24 \mathrm{~h}$ Treatment } \\
\hline & & ATRA & EC19 & EC23 & ATRA & EC19 & EC23 \\
\hline$\% \mathrm{SubG}_{0}-\mathrm{G}_{1}$ & $0.24 \pm 0.1$ & $0.14 \pm 0.1$ & $0.29 \pm 0.1$ & $0.46 \pm 0.1$ & $1.6 \pm 0.19^{* * *}$ & $4.5 \pm 0.6^{* * *}$ & $3.9 \pm 0.43^{* * *}$ \\
\hline$\% \mathrm{G}_{0}-\mathrm{G}_{1}$ & $67.2 \pm 10.1$ & $26.1 \pm 3.6$ & $39.1 \pm 6.7$ & $58.7 \pm 8.2$ & $37.1 \pm 4.5$ & $29.0 \pm 4.1$ & $32.7 \pm 4.6$ \\
\hline$\% \mathrm{~S}$ & $30.8 \pm 1.1$ & $57.5 \pm 8.1^{*}$ & $51.5 \pm 7.2 *$ & $34.0 \pm 4.1$ & $29.5 \pm 3.5$ & $44.0 \pm 8.2 * *$ & $47.6 \pm 9.1 * *$ \\
\hline$\% \mathrm{G}_{2} \mathrm{M}$ & $1.74 \pm 10.1$ & $16.3 \pm 1.9 *$ & $9.1 \pm 1.3 *$ & $6.8 \pm 0.8 *$ & $31.8 \pm 4.8^{* * *}$ & $22.5 \pm 3.1^{* * *}$ & $15.8 \pm 1.9^{* * *}$ \\
\hline$\% \mathrm{G}_{2} \mathrm{M} / \mathrm{G}_{0}-\mathrm{G}_{1}$ & $2.6 \pm 0.2$ & $62.5 \pm 8.8^{* *}$ & $23.4 \pm 2.8^{*}$ & $11.6 \pm 1.7^{*}$ & $85.7 \pm 16.3^{* * *}$ & $77.6 \pm 10.8^{* * *}$ & $48.3 \pm 6.8^{* *}$ \\
\hline
\end{tabular}

Data represent mean $\pm \mathrm{SEM}, n=3$. The significance in $p$-values for comparison with control untreated cells is indicated as * $p<0.05$, ${ }^{* *} p<0.01,{ }^{* * *} p<0.001$.

\subsection{Effect of ATRA and Synthetic Retinoids on Cell Invasion}

The principle for this assay depends on measuring the color intensity of deeply stained penetrated cells as a function of metastasis. Figure 4 shows the effect of ATRA, EC19 and EC23 at IC 50 concentration after 24 and 48 h of treatment on Caco- 2 cell invasion through the polycarbonate filter coated with collagen matrix (i.e., Transwell chamber). When Caco-2 cells were treated with $\mathrm{IC}_{50}$ of ATRA or EC-synthetic retinoids for $24 \mathrm{~h}$, there was obvious inhibition in Caco-2 cell invasion compared to control (ATRA (3.8\%), EC19 (7.2\%), and EC23 $(4.8 \%))$. As the time of incubation reached $48 \mathrm{~h}$, the percentage inhibition of Caco-2 cell invasion was increased by the effect of ATRA (8.6\%), EC19 (17.2\%) and EC23 (15.8\%). Also, there was obvious significant reduction in percentage of penetrated cells treated with EC19 after 24 and $48 \mathrm{~h}$ compared to both ATRA and EC23 (Figure 4). In the negative control chamber, cells that were stained deep violet were those that successfully invaded the lower surface of the filter as shown in Figure 5. The extent of penetration through the collagen matrix basement membrane by Caco-2 cells was decreased (indicated by the observable reduced violet dots of cells) upon treatment with synthetic retinoids (Figure 5).

\subsection{EC19 Reduced Intracellular Glutamate in Caco-2 Cells}

The intracellular and extracellular glutamate concentrations were measured as a proxy to reflect the overall changes in glutamate metabolism and release and to understand their correlation with the mechanism of EC-synthetic retinoids in cell growth. The cytosolic glutamate level was markedly reduced to $39.7 \%$ (EC19), 29.8\% (ATRA), and 16.8\% (EC23) compared to the untreated control after the manipulation of Caco- 2 cells with $\mathrm{IC}_{50}$ doses for $24 \mathrm{~h}$ (Figure 6). Also, there was significant reduction observed with EC19-treated cells compared to both ATRA- and EC23- treated cells. The released glutamate was also reduced; however, the magnitude of reduction was 24.1\% (by ATRA), $5 \%$ (by EC23) and $1.4 \%$ (by EC19). 
(A)

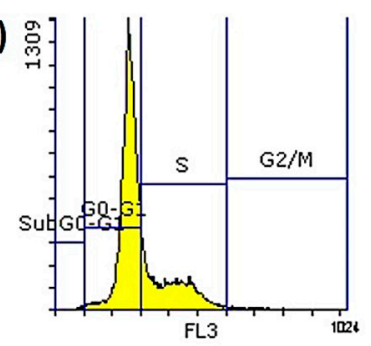

(B)
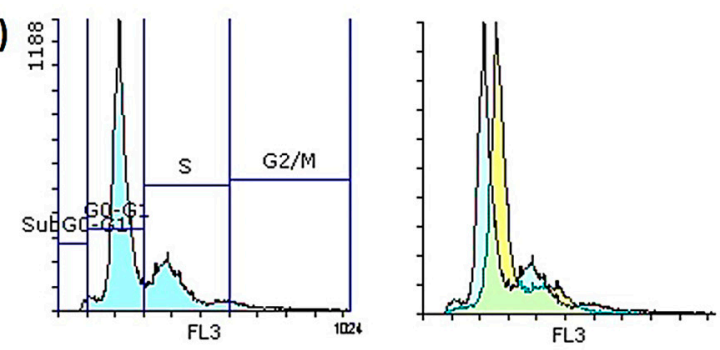

(C)
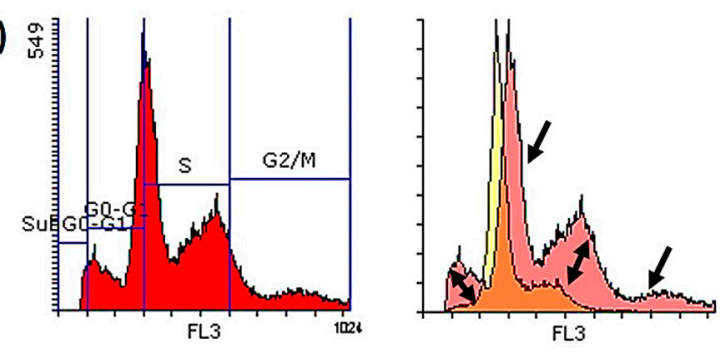

(D)
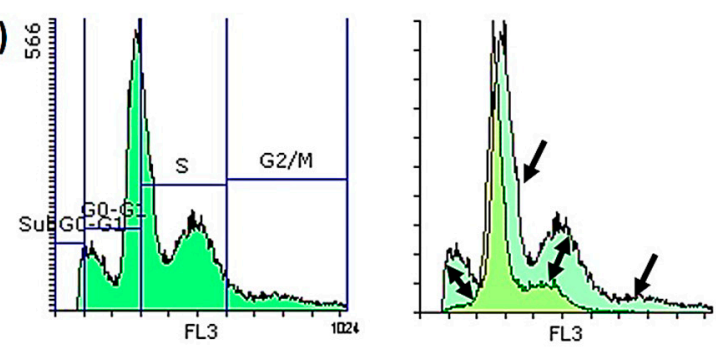

Figure 3. Cell cycle analysis (DNA analysis) of Caco-2 cells treated for $24 \mathrm{~h}$ with $\mathrm{IC}_{50}$ of retinoids. The histograms of (A) negative control exposed to $0.1 \%$ DMSO solvent (yellow histogram), (B) ATRA (blue histogram), (C) EC19 (red histogram), and (D) EC23 (green histogram) are shown, together with the overlay histograms of each synthetic retinoid compared to the solvent control. Regions of cell cycle arrest are indicated with black arrows reflecting the early apoptosis compared to control.

\subsection{EC19 and EC23 Reduce the Antioxidant Capacity of Caco-2 Cells}

Total antioxidant capacity (TAC), also called total antioxidant activity (TAO) was determined spectrophotometrically in cell lysates. Figure 7 shows that there were statistically significant differences in TAO values between untreated Caco- 2 cells and those treated with $\mathrm{IC}_{50}$ concentration of the synthetic retinoids for $24 \mathrm{~h}$. EC19 and EC23 showed a similar reduction in TAO $(22.6 \pm 0.024 \mu \mathrm{M} / \mathrm{L}, p<0.05)$ in comparison to the solvent control $(32.6 \pm 0.21 \mu \mathrm{M} / \mathrm{L})$. In contrast, ATRA induced a significant increase in TAO $(62.6 \pm 0.15 \mu \mathrm{M} / \mathrm{L}, p<0.05)$ in comparison to the solvent control. 


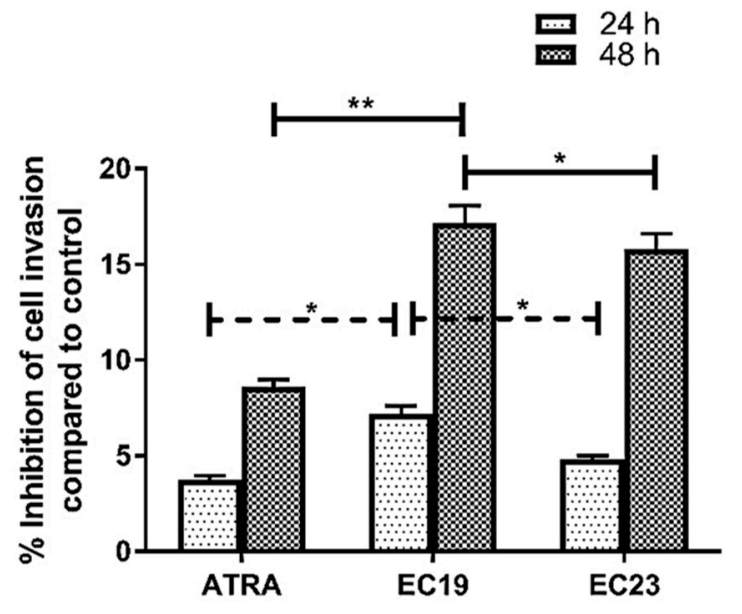

Figure 4. The percentage inhibition of Caco-2 cell invasion after the treatment with retinoids in comparison to the solvent control. The stain of invasive cells that traversed the membrane was extracted using the kit's extraction buffer and quantified at $490 \mathrm{~nm}$ using a microplate reader. The percentage reduction in absorbance (and thus invasion) by retinoids was calculated, in comparison to the DMSO-treated control, and plotted as mean \pm SEM of three independent experiments. The most significant reduction was observed with EC19 after $24 \mathrm{~h}$ and $48 \mathrm{~h}$ compared to ATRA and EC23. The significance in $p$-values for comparison is indicated as $*<0.05,{ }^{* *} p<0.01$.
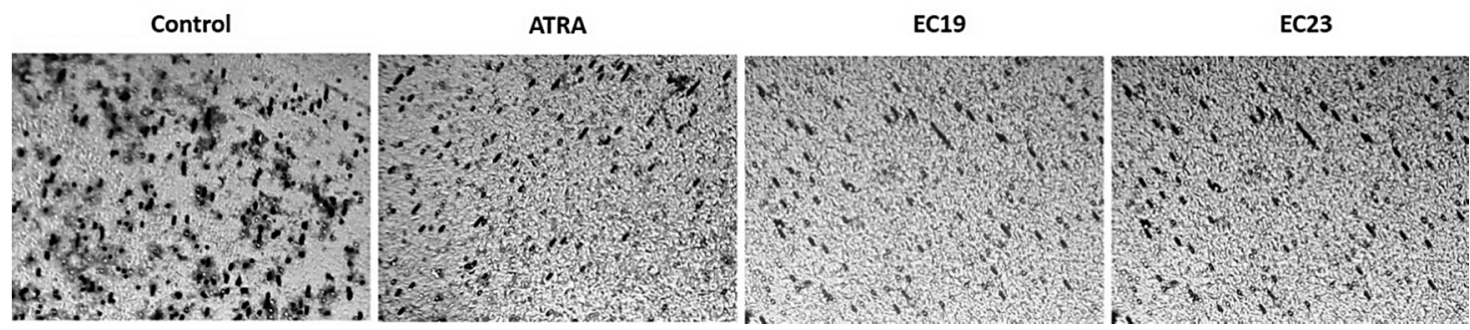

Figure 5. Transwell invasion assay shows the pattern of penetration of Caco-2 cells through the collagen matrix basement membrane. Cells were allowed to invade towards $10 \%$ fetal bovine serum for $48 \mathrm{~h}$ in the absence or presence of $\mathrm{IC}_{50}$ dose of ATRA and EC-synthetic retinoids. The cells penetrating the membrane were stained with violet dye.

\subsection{Gene Expression Analysis of Multiple Signaling Genes Affected by ATRA and EC-Synthetic Retinoids Treatments in Caco-2 Cells}

It was essential to investigate the possible mechanisms of the anticancer activity and the potency of the synthetic retinoid analogues using some selected signaling genes controlling the carcinogenesis in Caco-2 cells on the mRNA level. Data illustrations are for the $\mathrm{IC}_{50}$ doses of different retinoids after $24 \mathrm{~h}$ to explain the net response observed in the different aforementioned assays. Gene expression analysis was presented as fold-change; normalized to the control cells treated with $0.1 \%$ DMSO solvent. 


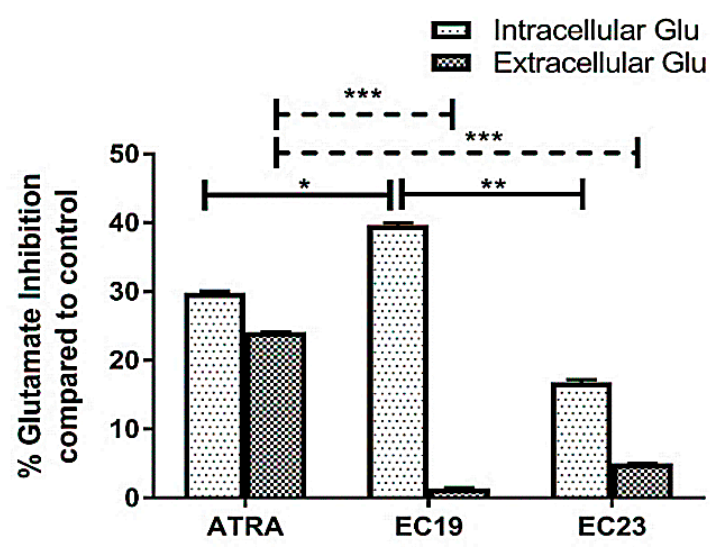

Figure 6. The percentages of both intracellular and extracellular glutamate inhibition. The reduction in glutamate levels was calculated after the manipulation of Caco- 2 cells with $\mathrm{IC}_{50}$ doses of ATRA and each EC-synthetic analogue. Data are presented as mean \pm SEM of three-independent experiments. Significant inhibition of intracellular glutamate with EC19-treated cells was observed compared to ATRA and EC23 treatments. Also, significant inhibition in extracellular secreted glutamate was observed with ATRA compared to both EC19 and EC23. The significance in $p$-values for comparisons is indicated as ${ }^{*} p<0.05,{ }^{* *} p<0.01$ and ${ }^{* * *} p<0.001$.

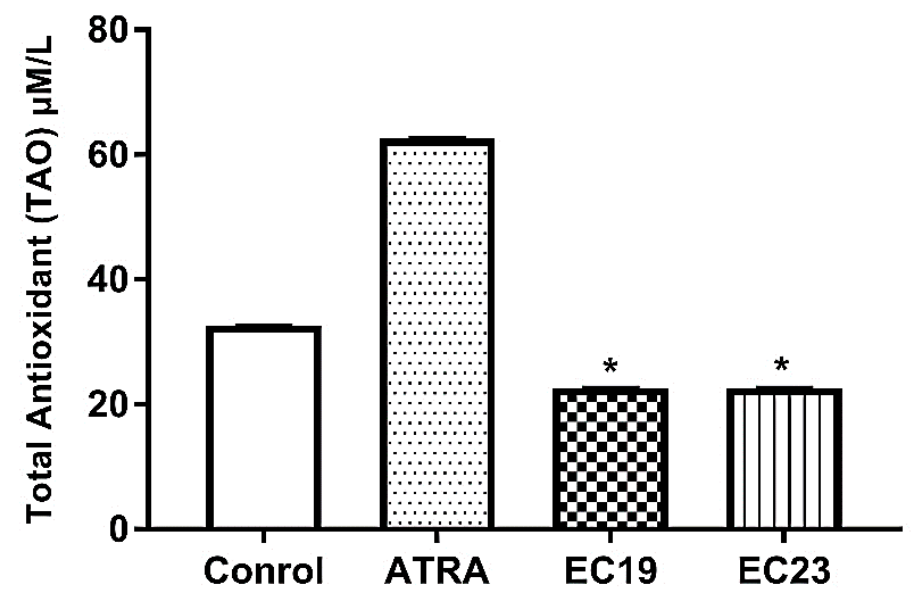

Figure 7. Total antioxidant activity (TAO) of retinoid-treated Caco-2 cells using $\mathrm{IC}_{50}$ dose for $24 \mathrm{~h}$. Both EC19 and EC23 induced a significant reduction in the total antioxidants compared to control (treated with $0.1 \% \mathrm{DMSO}$ ). Data is represented as the mean of TOA $\pm \mathrm{SEM}, n=3 .{ }^{*} p<0.05$.

\subsubsection{Gene Expression Analysis of Retinoic Acid Receptors (RARs)}

RARs are the primary cognate receptors receiving extracellular signals from retinoids including EC19 and EC23 [28]. The induction of RAR- $\beta$ transcription is well established as a marker of retinoid anticancer response [37]. Therefore, the expression of this gene was tested with respect to specified dose and time treatment, in addition to investigating the retinoid-induced changes in the expression of RAR- $\alpha$ and RAR- $\gamma$ (Figure 8A). Data obtained after $24 \mathrm{~h}$ of treatment with $\mathrm{IC}_{50}$ of different retinoids showed that ATRA, the natural RARs ligand, has a 35-fold increase in expression level of RAR- $\beta$, a 2.5-fold increase in RAR- $\gamma$ and no significant effect on RAR- $\alpha$ level. EC23 induced only 2.3-fold increase in RAR- $\gamma$ with no effect on the expression of other RARs. EC19 was the most potent EC-retinoid where it induced 131-fold increase in RAR- $\beta$ and 2.6-fold increase in RAR- $\alpha$ without affecting RAR- $\gamma$ expression. 

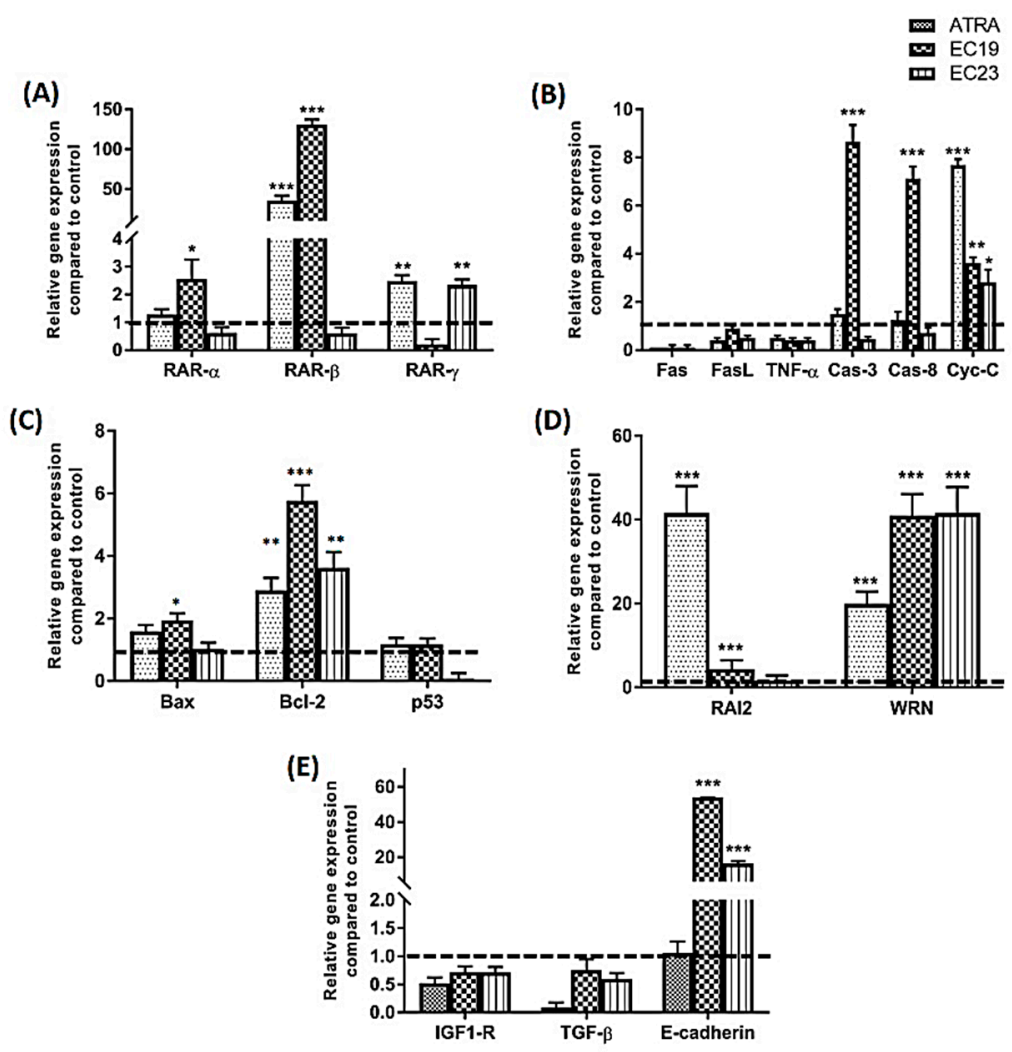

Figure 8. Gene expression analysis for different key genes after treatment of Caco-2 cells with $\mathrm{IC}_{50}$ of retinoids for $24 \mathrm{~h}$. Shown are (A) RARs $(\alpha-, \beta$ - and $\gamma-),(\mathbf{B})$ Key regulatory genes for extrinsic and intrinsic apoptosis, (C) apoptotic Bax, anti-apoptotic Bcl-2 and p53, (D) RAI2 and WRN genes, and (E) metastasis and invasion genes (IGF1-R, TGF- $\beta$ and E-cadherin). The quantification of target mRNA after retinoid treatment was relative to Caco-2 cells incubated with $0.1 \%$ DMSO vehicle for $24 \mathrm{~h}$ and was normalized to the internal reference gene glyceraldehyde 3-phosphate dehydrogenase (GAPDH) (dashed line at 1 ). Relative gene expression was calculated by $2^{\wedge-\Delta \Delta C t}$ method and presented as an average of three independent experiments. The values are considered statistically significant compared to solvent-treated control at ${ }^{*} p<0.05,{ }^{* *} p<0.01,{ }^{* * *} p<0.001$. Data are represented as mean \pm SEM, $n=3$.

\subsubsection{Gene Expression Analysis of Key Apoptosis-Related Genes}

Apoptosis is an essential pathway for retinoids as anticancer agents. Retinoids can induce cell death through either intrinsic or extrinsic pathways. However, there is always an overlap between two signaling pathways dedicated to the activation of the caspase protease family, which is ultimately responsible for elimination of cancer cells. Therefore, it was of value here to investigate the apoptotic mechanism of these synthetic EC-retinoid analogues as apoptotic agents and their potency in comparison to ATRA through measuring the changes on the transcriptomic level. The ability of EC-synthetic analogues to provoke apoptosis in Caco-2 cells was evaluated on the mRNA levels of apoptosis-related genes as shown in Figure 8B. In the present study, Fas, FasL, and TNF- $\alpha$ (death receptors or their ligands) were screened as genes of extrinsic apoptosis in Caco-2 cells [38]. Neither the EC-synthetic retinoids nor ATRA were able to induce the transcription of Fas, FasL or TNF- $\alpha$. Caspase- 3 and -8 (Cas-3 and Cas- 8 ) were also screened for their cascade activation of apoptosis. ATRA induced borderline expression of both caspases with 1.5-fold change (Cas-3) and 1.2-fold change (Cas-8). EC23 did not induce significant expression of any of the two selected caspases. In contrast, EC19 was the most potent retinoid that was able to induce 8.6-fold change (Cas-3) and 7.1-fold change (Cas-8). Additionally, cytochrome-C (Cyt-C) initiates the activation cascade of caspases once it is released into the cytosol [39]. The level of Cyt-C gene expression was screened, and it was found that all retinoids were 
able to induce over-expression of Cyt-C. However, ATRA showed the highest level of expression with 7.7-fold change, compared to 3.6-fold change (EC19) and 2.8-fold change (EC23). Other important mediators of apoptosis include p53, Bax and its counteracting partner Bcl-2 which are known to control the mechanistic activation of intrinsic apoptosis. Figure $8 \mathrm{C}$ shows that ATRA and EC19 had a similar borderline increase in $\mathrm{p} 53$ gene expression (1.2-fold change) while EC23 did not induce p53 upregulation. In addition, ATRA and EC19 induced over-expression of the Bax gene with 1.6- and 1.9- fold change, respectively, while EC23 was not able to induce any significant change in Bax gene expression. On the other side, Bcl-2, the anti-apoptotic gene, was still significantly highly expressed after treatment with all retinoids and this was consequently reflected with an overall Bax/Bcl-2 ratio of less than 1 .

\subsubsection{Gene Expression Analysis of Retinoic Acid-Induced 2 (RAI2) Expression in Caco-2} Cells

Retinoic acid-induced 2 (RAI2) is a novel tumor suppressor gene whose expression is downregulated in various types of cancer, including breast cancer and CRC [40]. Restoration of RAI2 expression has been linked to cell apoptosis induction and a good prognosis of colon cancer. Our results show that all retinoids induce upregulation in RAI2 expression after $24 \mathrm{~h}$ with 41.6-fold change (ATRA), 4.4-fold change (EC19) and 1.6-fold change (EC23) (Figure 8D).

\subsubsection{Gene Expression Analysis of WRN Expression in Caco-2 Cells}

Werner $(W R N)$ gene is a tumor suppressor gene that was demonstrated to be hypermethylated with reduced mRNA expression and low gene copy number in advanced CRC [41]. Hence, the restoration of WRN expression induces tumor-suppressor-like features and inhibits tumor growth and associated carcinogenesis [42]. Our data in Figure 8D showed that all retinoids induced over-expression of WRN gene where EC19 and EC23 had similar potency ( 40-fold change) compared to ATRA which induced 20-fold change expression of the gene.

\subsubsection{Gene Expression of Migration-Related Genes in Caco-2 Cells}

The migration and invasion features play vital roles in the development of colon cancer [43]. Some genes are highly modulated and involved in invasion control via epithelialmesenchymal transition (EMT) responses; including insulin-like growth factor-1 receptor (IGF1-R) [44], transforming growth factor- $\beta 1$ (TGF- $\beta 1$ ) [45]. and E-cadherin [46]. The data presented in Figure $8 \mathrm{E}$ depicted that all retinoids were able to significantly reduce the gene expression of IGF1-R and TGF- $\beta 1$ to the minimal levels. On the other side, recent studies correlate the morphological and phenotypic EMT-like changes with the down-regulation of the epithelial marker E-cadherin [46-48]. E-cadherin gene was over-expressed in both EC19 and EC23-treated Caco-2 cells with 54- and 16.3- fold changes, respectively. ATRA did not show any significant increase in the E-cadherin gene expression level (Figure 8E).

\subsection{Western Blotting Analysis of Key Apoptosis-Related Proteins}

To verify the observed effects from gene expression data for the tested compounds on the Caco-2 cell line, the protein levels of Bax, Bcl-2, Cyt-C, Cas-3 and p53 were investigated using Western blotting (Figure 9). While no significant change in the regulation of the pro-apoptotic Bax and the anti-apoptotic Bcl-2 proteins for all the tested compounds, both ATRA and EC19 caused increment in the level of activated Cas-3. Interestingly, the levels of Cyt-C and p53 proteins were significantly increased in Caco-2 cells exposed to EC19 compared to the control cells. 
(A)

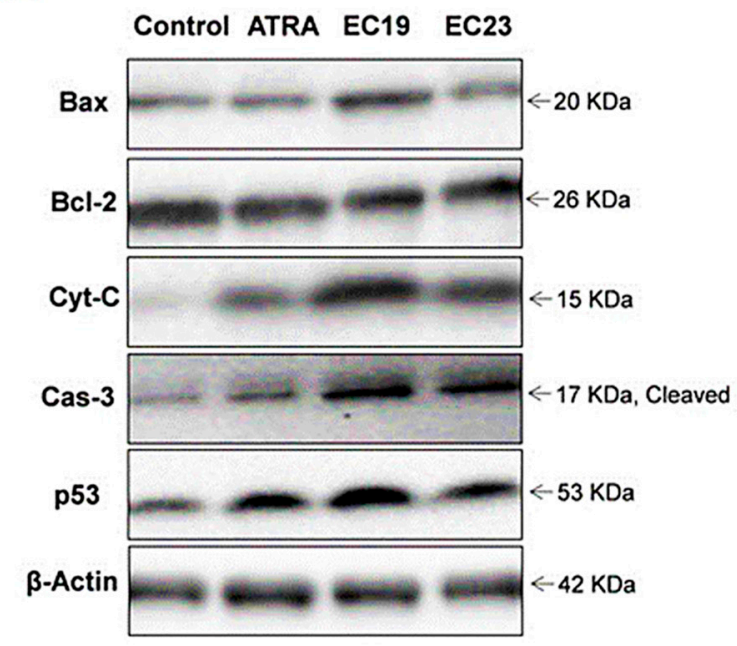

(B)

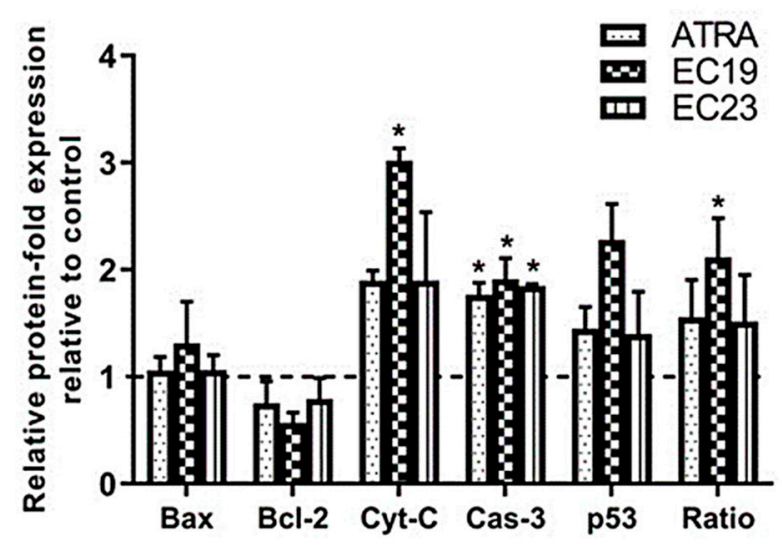

Figure 9. Western blotting analysis of Bax, Bcl-2, Cyt-C, Cas-3 p53 and Ratio (Bax/Bcl-2) in Caco-2 cells. (A) Representative immunoblotting images demonstrate the effect of $\mathrm{IC}_{50}$ dose of ATRA, EC19, and EC23 on the protein expression levels of Bax, Bcl-2, Cyt-C, cleaved Cas-3, and p53 in Caco-2 cells treated for 24 h. (B) Quantification of the tested proteins in Caco-2 cell lysates, with normalization to the $\beta$-actin protein (dashed line). The expression of all recorded proteins in the control group is set to (" 1 "), and all data from three separate experiments are fold change of proteins expression to control (dashed line) and shown as mean \pm SEM. ${ }^{*} p<0.05$ indicates a statistically significant difference from the matching vehicle-treated control group.

\subsection{Morphological and Immunocytochemistry Analysis of Caco-2 Cells Treated with Synthetic EC-Retinoids}

It is relevant here to report the morphological changes observed under the light phase inverted microscope after the exposure of Caco-2 cells to retinoids (specifically, EC19). Rounding of cells was observed in all retinoid-treated cultures (black arrows in light field images in Figure 10A with a higher extent in EC19, in addition to the cytoplasm condensation and the characteristic membrane "blebbing" [49,50]. Moreover, loss of contact, shrinkage, and formation of apoptotic bodies were observed as indications of morphological markers of apoptosis (Figure 10A) [51,52].

Cyt-C release is believed to occur following selective permeabilization of the mitochondrial outer membrane and therefore, it is considered a point of no return during cell death [53]. Thus, immunocytochemistry for cytosolic Cyt-C is a pivotal tool for understanding and characterizing the mitochondrial apoptosis pathway and the overall associated morphological changes. We have investigated the retinoid-induced release of $\mathrm{Cyt}-\mathrm{C}$ from mitochondria to the cytosol by labeling the $\mathrm{Cyt}-\mathrm{C}$ protein with a cytosolic green-fluorescent antibody and the cells' nuclei with Hoechst counter stain. The results show that the amount of Cyt-C protein in cytosol of retinoid-treated Caco-2 cells increased after $24 \mathrm{~h}$ (Figure 10A) compared to control cells treated with $0.1 \%$ DMSO. For quantitative analysis, the current techniques available to the assay of the Cyt-C release rely on cellular extraction followed by Western blotting, immunocytochemistry, or the subcellular localization of GFP-tagged Cyt-C [54]. Western blotting was used in this study; however, it is often difficult to quantify proteins on X-ray film if most of the apoptotic cells have cytoplasmic Cyt-C. Therefore, immunocytochemistry was used to assess the quantitative expression of the cytosolic fraction of Cyt-C using the high technology confocal microscopy and high sensitivity of Alexa Fluor 488 for quantitative analysis [55]. EC19 showed a significant increase in the Cyt-C protein released and number of positive cells expressing the marker compared to control cells (Figure 10B). This quantitative assessment represents the mean anti-Cyt-C antibody green fluorescence intensity emitted from all the cells scanned in the field. EC23 came in the second rank for the induction of $\mathrm{Cyt}-\mathrm{C}$ protein expression and the intensity followed by ATRA (Figure 10B). 


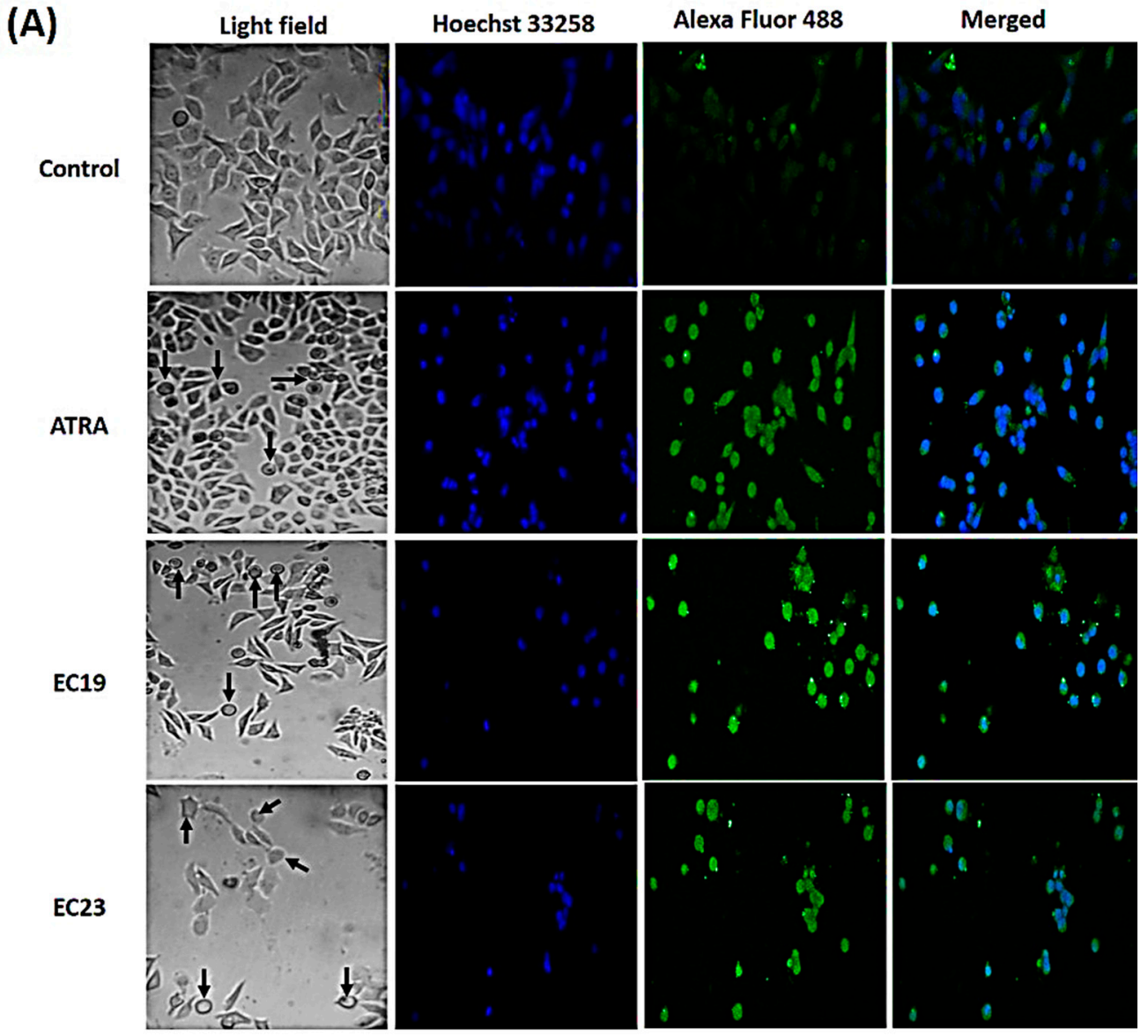

(B)

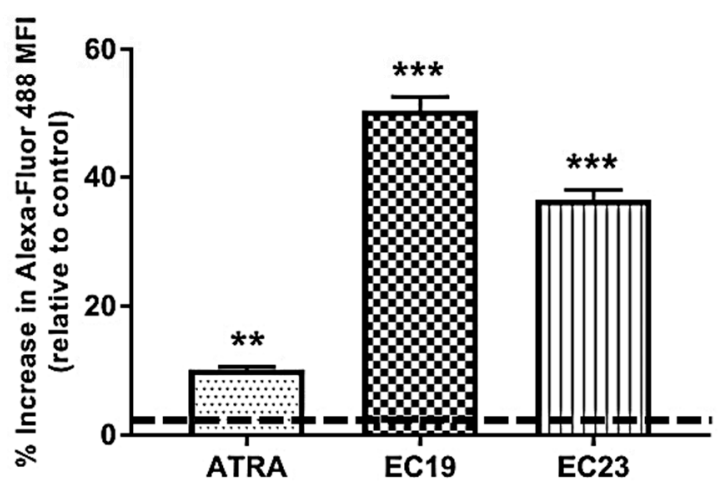

Figure 10. Cell morphology and immunocytochemistry of Caco-2 cells treated with $\mathrm{IC}_{50}$ of retinoids for $24 \mathrm{~h}$ and stained with anti-Cytochrome-C antibody. (A) Control Caco- 2 cells treated with $0.1 \%$ DMSO was compared to those treated with retinoids under an inverted microscope (OPTECH Biostar IB; magnification, 40×). Dark arrows indicate rounded apoptotic bodies. (B) Also, a comparative assessment of anti-Cytochrome-C staining of control cells, compared to cells treated with ATRA, EC19 and EC23, was performed. The most significant increase in Cytochrome-C protein expression level was demonstrated in EC19-treated cells followed by EC23 treatment and finally ATRA treatment in comparison to DMSO-treated control cells. The values were considered statistically significant in comparison to untreated control at ${ }^{* *} p<0.01,{ }^{* * *} p<0.001$. Results are expressed as the mean $\pm \operatorname{SEM}(n=3)$.

\section{Discussion}

3.1. Potent Antiproliferation with Minimal Cytotoxicity of EC-Synthetic Retinoids

ATRA is shown to induce differentiation and inhibits the growth of many types of cancer [15]. Regulatory and cytotoxic effects are mediated through several nuclear 
receptors and downstream mediators. However, cancer cells can rapidly develop resistance to natural retinoids [21]. Additionally, a larger dose from ATRA above the pharmacological dose $(10 \mu \mathrm{M})$ is required to reach $50 \%$ growth inhibition for different cancer cell lines and this was matched with our data results across several cancer cell lines. These observations prompted the demonstration of previously documented two synthetic derivatives of ATRA; EC19 and EC23 for the induction of neuro-differentiation, to inhibit the proliferation of many cancer cells, with shedding the light on their potency and cytotoxic adverse effects [27]. Several cancer cell lines were used of different origins including hepatocellular, breast, lung, prostate, and lung cancer cell lines in order to identify the most sensitive cancer type to EC19 and EC23. Cell viability assay identified EC19 as the most potent and selective to three cancer cell lines (Caco-2, HepG2 and MCF-7) whereas EC23 was selective to two cell lines (HepG2 and MCF-7). The selectivity index (SI) as marker of cytotoxic adverse effect was calculated in comparison to non-cancerous WI-38 cells, and it was found that both EC19 and EC23, but not ATRA, can be used in lower doses to preferably target cancer types such as Caco-2, HepG2 and MCF-7 cells.

\subsection{Caco-2 Cells is In Vitro Model for Further Anticancer Screening}

Caco-2 cells was chosen for further biochemical investigations in our study due to many reasons; (1) the global need for novel drugs in this type of cancer. (2) The number of FDA-approved drugs for the treatment of breast cancer and hepatocellular carcinoma greatly outweighs those approved for colon and CRC management and, hence, there is obvious scarcity in CRC cures. (3) Many of the drugs approved for the treatment of CRC are monoclonal antibodies with relatively high cost compared to repurposing available molecules in market such as EC-synthetic retinoids. (4) The major obstacle in the current available anticancer agents is their cytotoxicity to normal cells while treating CRC $[15,56]$. (5) CRC is one of the most frequently diagnosed cancer types in both men and women and is the third most common cause of cancer mortality worldwide [57]. Finally, specific modulation in signaling pathways in Caco-2 cells including retinoid pathways is associated with metastasis, tumorigenesis as well as resistance to retinoids treatment and progression from normal colon mucosa to carcinoma. Hence, all these reasons were important, interesting and challenging to understand the potency and antiproliferative mechanism of EC19 and EC23 in Caco-2 cells.

\subsection{A Promising Synergistic Combination with 5-FU in Caco-2 Cells}

It was also interesting to consider whether EC-synthetic retinoids would reveal similar synergistic, antagonistic, or additive effects when combined with 5-FU chemotherapeutic agent. Despite the promising results in the treatment of many cancers, the doses required for successful therapy with ATRA are often toxic, leading to "hypervitaminosis-A syndrome" [58]. A possible solution to this problem is to combine ATRA, or other structurally related retinoids, with other chemotherapeutic agents. Co-administered drugs may either reduce or enhance the efficacy of each other's depending on the therapeutic window of the combined drugs [59]. Although the antimetabolite 5-fluorouracil (5-FU) has been the only drug available to successfully improve 12-month survival in CRC patients, clinical resistance is continuing to be a challenge to date [60]. The combination strategy has become especially important in CRC due to frequent resistance to 5-FU and different anti-cancer drugs that are administered at or close to the maximally tolerated dose [61,62]. Studies showed a synergistic cytotoxic effect of ATRA when combined with 5-FU in CRC and other cancer types $[63,64]$. Isobologram analysis was an important indicator to provide us with the evidence for drug interactions [65]. Results showed promising synergistic effect of the retinoids in combination with 5-FU on the proliferation of Caco-2 cells with a reduction in all combined $\mathrm{IC}_{50}$ values by about $11-17 \%$. Also, DRI and CI confirmed this synergistic effect. Our suggested hypothesis is that synthetic retinoids can act in a way similar to ATRA and can work together with 5-FU by different molecular pathways mainly through the action on RARs nuclear receptors to achieve their overall cytotoxicity to cancer 
cells. RARs were shown to be members of nuclear receptors that modulate different pathways controlling cancer growth and metastasis [66] like apoptosis [67], kinases-dependent pathways [68] and others. Unlike many chemotherapeutic drugs, synthetic retinoids such as EC19 and EC23 can be active at lower doses and over longer periods of incubation due to the environmental and cellular stability $[27,69]$ which could further support their additive effects. Hence, EC-synthetic combinations would be more beneficial than ATRA in clinical settings due to their observed potent effect in relatively lower doses than individual standard retinoids. This may pave the way for future in vitro and in vivo combination strategies that impact patient overall survival, reduce the possible side effects and optimize the treatment outcomes.

\subsection{The Antiproliferative Effect of EC19 and EC23 in Caco-2 Cells is Due to Early Apoptosis and Cell Cycle Arrest}

Determining the mechanism of actions of EC- synthetic retinoids in caco- 2 cells was essential for advancing our understanding of these compounds in the sake of effective therapeutic alternatives. Many studies suggested that the effects of retinoids on cell proliferation, cell cycle, and apoptosis are either retinoid specific or cell-type specific [70-73]. These findings led to the successful clinical application of different retinoids in the treatment or prevention of various human cancers including Caco-2 cells. Also, studies in Caco-2 cells and other cell types suggest that ATRA and other natural isoforms cause arrest of cells in the $G_{1} / S$ phase of the cell cycle and increase the percentage of cells in $G_{0}-G_{1}$ boundary $[70,74,75]$. This observation has been demonstrated in our results as ATRA and EC19 were able, after 12-h incubation, to induce slight cell cycle arrest in both S- and $\mathrm{G}_{2} / \mathrm{M}$ phases (this effect was exaggerated after $24 \mathrm{~h}$ ), in addition to subG $\mathrm{G}_{0}-\mathrm{G}_{1}$ phase arrest. This effect may arise from the integration between the retinoid-induced differentiation and apoptosis since retinoic acid-induced phenotypic differentiation at early-stage and late apoptosis is time- and concentration-dependent [76,77]. In terms of the potency, EC19 and EC23 were able to significantly reduce the percentage of viable cells and increase the early apoptotic cells compared to both ATRA and negative control. This was confirmed by the calculation of AI for both EC19 and EC23. These results are matched with the difference observed in antiproliferative potency of EC19 and EC23 on Caco-2 cells and may suggest their apoptotic mechanistic effect. The apoptotic effect was previously documented for ATRA and many synthetic retinoids [71,73].

\subsection{Differential Transactivation of RARs Explains the Differential Sensitivity of Caco-2 Cells}

In a previous report, ATRA was shown to have a pro-differentiating effect in Caco-2 cells [78], probably by stimulating the expression of RAR- $\beta$ via a retinoic acid response element (RARE) [79]. Furthermore, the expression of RAR- $\beta$ is downregulated in many cancers, including colon cancer [80]. The findings of the present study fit into the context of these results. We found that ATRA selectively enhances the mRNA level of RAR- $\beta$ after $24 \mathrm{~h}$. Similarly, EC19 stimulates the expression of RAR $\beta$ after $24 \mathrm{~h}$; however, the effect at $\mathrm{IC}_{50}$ appears to be much higher than ATRA (approximately 10-folds higher) in contrast to EC23 that did not show any significant increase in RAR- $\beta$. Transactivation of RAR- $\beta$ gene has been previously linked to the cellular arrest and apoptosis in $s u b G_{0}-G_{1}$ phase in a wide variety of cancer types including CRC [81]. Hence, natural retinoids have RAR- $\beta$-based tumor-suppressive activity, and loss of normal RAR- $\beta$ function is associated with the progression of a diverse range of cancers [82]. For instance, RAR- $\beta$ activity was markedly increased in HT-29 cells exposed to ATRA leading to the activation of p53/p21 signaling pathway [83]. The activated $\mathrm{p} 21^{\text {Waf1/Cip1 }}$ inhibits the cyclin-dependent kinases (CDKs) and consequently induces cellular subG $\mathrm{G}_{0}-\mathrm{G}_{1}$ arrest. These observations may suggest that the reduction in cellular proliferation observed during the viability and apoptosis assays was due to $s u b G_{0}-G_{1}$ arrest downstream of RAR- $\beta$ stimulation. Moreover, RAR- $\alpha$ is expressed mainly in adult tissues while RAR- $\gamma$ is expressed in skin tissues [84] and their gene overexpression in tumor cells leads to growth inhibition and accumulation of cells in the subG $\mathrm{G}_{0}-\mathrm{G}_{1}$ phase of the cell cycle [84-86]. These differential activities may explain 
the enhanced antiproliferative activity of EC19 due to both RAR- $\beta$ - and RAR- $\gamma$ - mediated activity compared to only RAR- $\gamma$ - dependent action by EC23. There are comparable cellular mediated results of ATRA and EC19 on both RAR- $\beta$ - and RAR- $\gamma$ to our previously reported molecular selectivity of these molecules to these receptors while EC23 was different in response which may be due to other resistance factors in Caco- 2 cells to activity of EC23 molecule [28].

\subsection{Phenotypic Perturbations Seen under Microscope are Pertinent to Apoptosis Induction}

The morphological observation confirmed the apoptotic effect where control cells treated with media containing $0.1 \%$ DMSO were packed as a tight and adherent monolayer to the well surface. On the other side, Caco-2 cells exposed to retinoids, particularly EC19, showed obvious cytoplasmic condensation, characteristic membrane "blebbing", loss of contact, shrinkage, and formation of apoptotic bodies. These changes are indicative of apoptosis with different extents according to the potency of each compound $[49,50]$.

\subsection{The Molecular Changes of EC-Synthetic Retinoids on Transcriptomic and Proteomic Levels}

Tracking and understanding the mechanism of apoptotic activity of EC-synthetic analogues on the genetic level is important to conclude their potential use in further in vivo studies and future clinical applications. Apoptosis is a major anticancer mechanism that is initiated through one of two main pathways: the intrinsic and the extrinsic pathways. The intrinsic pathway is called mitochondrial apoptosis where the cell kills itself through the activation of intracellular mediators that loosen the mitochondrial membrane and induce the release of mitochondrial contents [87]. The other form is extrinsic apoptosis where cells sense the stress caused by signals from the external environment [88]. Caspases play an important role in anticancer drug mechanisms to create an overlapping hub between the two signaling pathways in response to a specific drug to eliminate cancer cells. In this regard, the ability of EC19 to provoke apoptosis in Caco-2 cells resulted in a significant up-regulation of the expression level of caspase- 8 , the leading early caspase type in the extrinsic pathway which converges to caspase-3 as a key executioner of apoptosis [89]. The protein expression level of caspase-3 was significantly increased with EC19, matching what was seen in the gene expression assay. Moreover, $\mathrm{Bcl}-2$ and Bax are two discrete members of the family of genes involved in resistance to many apoptotic stimuli including the most conventional cytotoxic anticancer drugs [90,91]. Bax and Bcl-2 genes are responsible for switching on/off apoptotic mechanisms and are considered as important gatekeepers to the apoptotic response. While Bcl-2 gene is functionally characterized as an apoptosissuppressing factor, the Bax protein is more functionally characterized as an apoptosispromoting factor. Therefore, the intracellular Bax/Bcl-2 ratio can profoundly influence the ability of a cell to respond to an apoptotic signal [92,93]. EC19 was able to induce up-regulation of the expression level of the pro-apoptotic Bax gene with about 2 fold higher than control and this was confirmed on protein expression level as well.

\subsection{The Modulation of Cyt-C Expression with EC-Synthetic Retinoids Treatment is Indicative of} Intrinsic Apoptosis Induction

The activated Bax binds to the mitochondrial outer membrane leading to the opening of the mitochondrial voltage-dependent anion channel (VDAC) followed by the release of Cyt-C from the mitochondria into the cytosol where it activates the caspase-dependent signaling and subsequent apoptosis. Therefore, the $\mathrm{Cyt}-\mathrm{C}$ release from mitochondria is an indicator of activation of the intrinsic apoptotic pathway [94]. Herein, we assessed the expression level of $\mathrm{Cyt}-\mathrm{C}$ on the gene and protein levels in order to assure the adoption of the intrinsic pathway for apoptosis induction [95]. The level of the Cyt-C transcription was induced quickly after $24 \mathrm{~h}$ with a higher level for ATRA followed by EC19 and EC23. However, Cyt-C protein level detected using Western blotting and immunocytochemistry showed a significant increase with EC19 compared to other retinoids. This difference in observation despite the optimization of procedures might suggest some explanations; first, for the intrinsic pathway of apoptosis induced by EC19, the gene expression of Cyt-C 
is not the major determinant of its protein level, and there might be other contributing factors controlling the potency of EC19 in apoptosis. Also, EC19 might have an effect on other regulatory processes controlling mRNA translation, miRNA targeting species and post-translational modifications, like phosphorylation, acetylation and glycosylation and hence, increasing the stability of mRNA and protein products and this is something we are working-on currently in the project [96].

\subsection{EC19-Induced Apoptosis in Caco-2 Cells Involves the Induction of p53 Protein Expression}

Another major apoptosis signaling pathway involves the p53 tumor suppressor protein [97]. The ability of p53 to control apoptosis in response to abnormal proliferative signals and stress is crucial for its tumor suppression role. The p53 is a nuclear transcription factor that regulates the expression of a wide variety of genes involved in apoptosis. It is able to induce Bax oligomerization and Cyt-C release from mitochondria [98]. Gene expression analysis of p53 did not show any significant increase in its level after $24 \mathrm{~h}$; however, the protein expression level was significantly increased with EC19 and this might suggest the preferential role of EC19 on the stability of protein product compared to other retinoids. Overall, the EC19 predominant apoptotic effect is due to stable over-expression of intrinsic key genes and proteins of apoptosis including Bax, p53, Caspas-3, Cyt-C.

\subsection{The Reduction of the Intracellular Glutamate Pool May Further Explain the Superior Activity of EC19 over EC23 in Caco-2 Cells}

Glutamate is an essential molecule for cells, especially cancer cells due to its paracrine effect on intracellular and extracellular communications where even the small changes in its levels significantly impact the cellular transformation and cancer progression [99-101]. The extracellular glutamate is mainly required for intercellular communication and activation of survival pathways, like the MAPK and PI3K pathways, promoting growth and invasion [101,102]. Also, glutamate is the most abundant amino acid used by highly proliferating cancer cells to increase proliferation since it is converted to $\alpha$-ketoglutarate $(\alpha-K G)$ and channeled into the TCA cycle [103]. Moreover, glutamate has an important role in the creation of cellular building blocks for cancer cell growth such as nonessential amino acids and nucleotides to survive under metabolic stress conditions [104-106]. Finally, glutamate is required for intracellular glutathione production, which is a pivotal molecule for an adequate oxidative status of cancer cells [107]. Therefore, depleting the cellular stores of glutamate ameliorates cellular defense against reactive oxygen species (ROS), reduces intercellular communication through glutamate-dependent signaling pathways and may lead to lower levels of ATP and essential nutrients [108]. Previous studies showed an interesting negative correlation between glutamate enrichment and activation of retinoid signally pathway of RARs, RXRs, and peroxisome-proliferator-activated receptor (PPAR) pathways [109]. These nuclear receptors act as partners for dimerization and translocation to the nucleus for deactivating the glutamate enrichment and tumorigenesis [109]. Any deregulation in the function of these nuclear receptors, especially RAR- $\alpha$ and $-\beta$, can be associated with glutamate formation and release [109]. Hence, the concentration of extracellular and intracellular glutamate plays an important role to understand if the antiproliferative activities of retinoids are mediated, at least in part, through the inhibition of glutamate synthesis and secretion $[105,110]$. Therefore, a glutamate assay is an important tool that further confirmed EC19 potency as an antiproliferative agent since it was able to reduce $40 \%$ of the total intracellular glutamate and consequently lower the amount of glutamate that was released extracellularly (unlike ATRA and EC23). Moreover, because the glutamine/glutamate ratio is controlled by glutaminase and glutamine synthetase [107], the interference with glutaminase activity could be a possible explanation for the reduction of glutamate levels. Nevertheless, further investigation is required to accurately confirm the main players controlling the cellular glutamate metabolism. 


\subsection{EC-Synthetic Retinoids are Pro-Oxidants that Promote Cellular Vulnerability to Oxidative Stress}

Oxidative stress may be an early event in the activation of the apoptotic machinery [111]. Proteins and DNA are prone to mutations and/or damage by oxidative stress causing different pathological conditions. This is evident when ROS increase in cancer cells, such as CRC, where they were found to be cytotoxic. Thus, ROS-mediated DNA damage halts the malignant transformation of cancer cells and suppresses tumorigenesis [112]. Therapeutic candidates that promote cellular pro-oxidant state could favorably destroy CRC cells through enhancing cellular oxidative stress. Here, both EC19 and EC23 significantly reduced the cellular TAC. The ability of these compounds to significantly reduce cellular TAC may be connected with their anti-tumorigenic outcome as the cells become more prone to pro-oxidants. Additionally, the glutamate depletion, which is a major determinant for the concentration of one of the most pivotal antioxidant molecules (i.e., GSH), may explain, at least in part, the profound potency of EC19 for the reduction in total antioxidant capacity in Caco-2 cells [113-115].

\subsection{Retinoids Reduce the Metastatic Potential of Caco-2 Cells via Modifying the Expression of Relevant Genes}

The interaction between primary tumor cells and host vasculature is an early step during tumor development and results in poor prognosis owing to the active migration of tumor cells into adjacent tissues through metastasis and invasion [116]. During the process of invasion, tumor cells penetrate basement membranes either to reach the interstitial stroma or to gain access to bloodstream [117]. Retinoic acid has been shown to reduce the cell-cell and cell-matrix adhesion of human intestinal epithelial cells to culture flasks and plastic dishes [117]. Also, retinoids were shown to reduce the metastatic potential of ATRAresistant colon cancer cells via a RAR-independent mechanism that involves reduced matrix metalloproteinase (MMP) mRNA levels and activity [118]. Various degradative enzymes, either in the tumor cells or in host cells, are induced to do so by tumor-derived factors related to retinoid signaling such as $R A I 2$ or through retinoid-independent metastasis modulators such as $W R N$, IGF1-R, TGF- $\beta 1$ and E-cadherin.

IGF1-R is often elevated in many cancer tissues including colon cancer and its activation has been linked to increased NF- $\mathrm{kB}$ activation and thus proliferation, survival, metastatic potential, and angiogenesis $[119,120]$. Therefore, targeting IGF-1R is a promising approach in anticancer therapeutics. Transforming growth factor-beta (TGF- $\beta$ ) is another potential contributor to both angiogenesis and CRC tumor progression [121]. TGF- $\beta$ has a characteristic mechanism of activation through binding a dimer of type II receptors (TGF $\beta R$-II) leading to the recruitment of TGF $\beta$ R-I (ALK5) and consequent phosphorylation of R-Smad2 and R-Smad3 [122]. These R-Smads complex with Smad4 and associate with transcriptional factors in order to regulate the expression of target oncogenes controlling Caco-2 cell growth, invasion, epithelial to mesenchymal transition, evasion of immune surveillance, and metastasis $[123,124]$.

E-cadherin is another invasion-orchestrating marker that acts as a core component of epithelial adherent junctions and, thereby, essential for colon tissue development, differentiation, and maintenance [125]. The colon is lined by an epithelial monolayer secreting E-cadherin that acts as a signaling epicenter regulating cell behavior in response to intraand extra-cellular stimuli. In colon cancer, E-cadherin has been extensively studied and linked with many pathways including Wnt/ $\beta$-catenin signaling; therefore, dysregulation of this pathway is a predominant driver of colon tumorigenesis [126]. Two contradicting roles have been reported for the E-cadherin; the first is a predominant tumor-suppressing role to interfere with the pro-tumorigenic transformation that is promoted by $\beta$-cateninactivating mutations as well as a role in intracellular signaling that ultimately inhibits metastasis [125].

Retinoic acid-induced $2(R A I 2)$ has been recently identified as a transcriptional regulator that controls the expression of several key regulators in cancer [127]. Low expression of RAI2 was detected in breast and CRC cancers and it was associated with early-onset 
bone metastasis in ER $\alpha$-positive breast malignancies $[127,128]$. In colon cancer, restoration of RAI2 expression suppressed CRC cell proliferation, migration, and invasion, as well as induced programmed cell death [40]. Also, the Werner (WRN) gene, which is a human RecQ DNA helicase with both a $3^{\prime}$ to $5^{\prime}$ helicase activity and a $3^{\prime}$ to $5^{\prime}$ exonuclease activity [129], has been identified as a tumor suppressor gene where any germline mutation in its sequence can cause Werner's syndrome (WS) with an increased risk of tumor development [130]. A recent study highlighted its role in CRC and stated that the downregulation of WRN is "highly associated" with late-stage CRC. A possible link between the WRN gene and the intracellular cell signaling of retinoids has been postulated to be a key regulator of retinoic acid-induced stem cell differentiation [131]. Moreover, WRN is among the key regulators of p-53-mediated transcriptional activity. High WRN expression induces the transcription of p53-orchestrated genes leading to enhancement of p53-mediated cell cycle arrest and subsequent apoptosis [132].

Our results were in agreement with the potential roles of these aforementioned networking mediators where the exposure of Caco-2 cells to ATRA and EC-synthetic analogues restored the expression of E-cadherin, RAI2 and WRN genes with significant downregulation of IGF1-R and TGF- $\beta$. EC19 had the most potent activity in inducing the overexpression of E-cadherin and WRN genes whereas ATRA was mainly a potent inducer of $R A I 2$. Moreover, the invasion assay confirmed the results as all retinoids were able to inhibit the invasion of Caco-2 cells through the collagen matrix membrane and EC19 showed the highest inhibitory activity in a time-dependent manner followed by EC23 and ATRA.

\section{Materials and Methods}

\subsection{Retinoids Solution}

EC19, EC23, and ATRA were purchased as ready to use powder from (Clinilab, Tocris Biosciences, UK; purity $\geq 98 \%$ (high-performance liquid chromatography, HPLC)) and stock solutions were prepared in DMSO (Sigma-Aldrich) as a concentration of $1 \mathrm{mM}$. Aliquots from the stock solution were stored at $-20^{\circ} \mathrm{C}$ freezer. ATRA stock solution and different working concentrations aliquots were kept away from light during storage and along the experiments.

\subsection{Cell Culture}

All cancer and normal cell lines used in this study were purchased from the cell culture bank in tissue culture unit at the Holding company for the production of vaccines, sera, and drugs (VACSERA, Giza, Egypt). Different types of cancer cell lines were selected including hepatocellular carcinoma (HepG2 and Huh-7), breast cancer (MCF-7 and MDAMB-231), colorectal carcinoma (Caco-2, HCT-116 and HT-29), lung cancer (A549), and prostate cancer (Du-145 and PC3), in addition to two normal cell lines: healthy African green monkey kidney cells (Vero) and normal human lung fibroblasts (WI-38). All cell lines were maintained in the Center of Scientific Excellence "Helwan Structural Biology Research, (HSBR)" under standard laboratory conditions. Standard culturing conditions were performed by using culture media supplemented with $10 \%$ fetal bovine serum (FBS) and $1 \%$ penicillin/streptomycin, and the cells were incubated at $37^{\circ} \mathrm{C}$ in a humidified atmosphere containing $5 \% \mathrm{CO}_{2}$. Additionally, all cell cultures were handled carefully in reduced light conditions to account for the photosensitivity, and thus instability, of ATRA.

\subsection{Antiproliferation assay and Selectivity Index (SI) Calculation}

The antiproliferation and cytotoxicity were assessed using 3-(4,5-dimethylthiazol-2yl)-2,5-diphenyltetrazolium bromide (MTT, Serva) colorimetric assay [133]. To investigate the antiproliferation, all cell lines were seeded at a density of 20,000 cells per well in $96-$-well plates and allowed to adhere overnight. The attached cells were treated with five series concentrations $(0.01,0.1,1,10$, and $100 \mu \mathrm{M})$ of synthetic retinoids (EC19 and EC23) and ATRA (standard retinoid positive control) in triplicate. These concentrations were prepared by diluting the stock solutions with serum-free culture media. The negative control cells 
were those treated with $0.1 \%$ DMSO solvent alone. The treated cells were handled in reduced light and maintained under standard culture growth conditions for $24 \mathrm{~h}$. After the incubation period, MTT powder was prepared as a stock solution $(5 \mathrm{mg} / \mathrm{mL})$ and $20 \mu \mathrm{L}$ of the MTT working reagent (final concentration $0.5 \mathrm{mg} / \mathrm{mL}$ ) was added to each well. This was followed by incubation with MTT reagent for $4 \mathrm{~h}$ in a humidified atmosphere $\left(37^{\circ} \mathrm{C}\right.$, $5 \% \mathrm{CO}_{2}$ ) with subsequent addition of $150 \mu \mathrm{L}$ of DMSO solubilizing solvent and incubation for $20 \mathrm{~min}$. The absorbance of solubilized violet formazan crystals was measured at $540 \mathrm{~nm}$ with Biotek 800 TS microplate reader. IC $_{50}$ was calculated as the concentration of retinoid that produced $50 \%$ cell growth inhibition. For cytotoxicity assessment, WI-38 normal human fibroblast cells were used for the calculation of SI which is the ratio of $\mathrm{IC}_{50}$ retinoid (WI-38)/IC 50 retinoid (cancer cell line) [134]. Increasing SI value above 1 indicates a more effective and safer drug as an anticancer compared to normal tissues [135].

\subsection{Isobologram Analysis of Combined Drug Effect}

5-fluorouracil (5-FU) is a standard chemotherapy with known activity on Caco-2 cells and reported side effects $[136,137]$. The previously mentioned procedure of antiproliferation assay was used to evaluate the combined effects of retinoids and 5-FU to enhance the chemo-sensitivity of drugs and reduce the toxic $\mathrm{IC}_{50}$ doses. Cells were treated with a fixed ratio of combined agents simultaneously at doses that typically corresponded to 4 , $2,1,0.5,0.25$ and $0.125 \times$ times the individual $\mathrm{IC}_{50}$ values of each retinoid and 5 -FU. The results were quantified using "multiple-drug effect analysis" based on the isobologram technique originally developed by Chou and Talalay [138,139]. This mathematical model allows the determination of CI (combination index) values based on the Equation (1) [140]:

$$
\mathrm{CI}=\mathrm{d} 1 / \mathrm{D} 1+\mathrm{d} 2 / \mathrm{D} 2
$$

where $\mathrm{d} 1$ and $\mathrm{d} 2$ are the doses of drug 1 and drug 2 that, when given in combination, produce a specific response. D1 and D2 are the doses of drug 1 and drug 2, that, when given individually, produce the same response. Also, $\mathrm{CI}<1$ is synergy, $\mathrm{CI}=1$ is additivity and $\mathrm{CI}>1$ is antagonism

The DRI is defined as "the fold decrease in the dose of each drug if two drugs are given in combination, as opposed to individual treatment, to achieve a particular level of cytotoxicity" and is calculated from the Equation (2) [141]:

$$
\text { DRI }(\text { for } \operatorname{drug} 1)=\mathrm{D} 1 / \mathrm{d} 1
$$

DRI $>1$ reflects favorable dose reduction and consequently greater DRI value means a more favorable drug combination. DRI $<1$ indicates unfavorable dose reduction and ineffective combination. DRI that equals to 1 means there was no reduction in the dose for the selected drug [142].

\subsection{Detection of Apoptosis Using Annexin V (AV)/Propidium Iodide (PI) Assay}

The ability of synthetic retinoids to induce apoptosis in one of the sensitive cancer cell lines (namely, Caco-2 cells) was detected by Annexin V-FITC and PI according to the protocol of the detection kit (Beckman Coulter, Brea, CA, USA) [143]. In brief, cell suspension was cultured in $25 \mathrm{~cm}^{2}$ flasks overnight and then a number of flasks was divided into groups and treated with the $\mathrm{IC}_{50}$ concentration of retinoids for either 12 or $24 \mathrm{~h}$. Cells were collected, washed with phosphate-buffered saline (PBS) (Lonza), and resuspended in $1 \mathrm{~mL}$ of binding buffer. $100 \mu \mathrm{L}$ cell suspension was incubated with $1 \mu \mathrm{L}$ FITC-labeled Annexin V and $5 \mu \mathrm{L}$ PI for $15 \mathrm{~min}$ at $4{ }^{\circ} \mathrm{C}$ in the dark. Finally, $400 \mu \mathrm{L}$ ice-cold binding buffer was added, and the apoptotic cells in each sample were analyzed by Beckman Coulter Epics XL flow cytometer. Apoptotic index (AI) was calculated as the number of apoptotic cell deaths expressed as a percentage from the total gated cells [144,145]. 


\subsection{Cell Cycle Analysis}

The cell cycle analysis was performed using flow cytometry (Beckman Coulter, Brea, CA, USA). Briefly, $1 \times 10^{6}$ Caco-2 cells were seeded into a number of $25 \mathrm{~cm}^{2}$ flasks overnight which were then divided into two groups and treated with $\mathrm{IC}_{50}$ of retinoids for either 12 or $24 \mathrm{~h}$. After incubation, cells were harvested, fixed with $70 \%$ alcohol overnight, and stained with PI ( $50 \mu \mathrm{g} / \mathrm{mL})$. DNA content was measured by Beckman Coulter Epics XL flow cytometer and $G_{0} / G_{1}, S$, and $G_{2} / M$ cells were gated as appropriate using Flowing Software 2.5.1 (Turko Bioimaging, Turku, Finland).

\subsection{Gene Expression Analysis of Multiple Signaling Key Genes}

Sensitive cancer cell line (Caco-2) was used for gene expression analysis of different genes controlling differentiation, apoptosis, tumor resistance, aggressiveness, and metastasis. Cells were seeded overnight at a density of $1 \times 10^{6}$ cells per well in 6-well plates in triplets at the standard incubation conditions, and then treated with $\mathrm{IC}_{50}$ concentrations of retinoids for $24 \mathrm{~h}$ in addition to the DMSO-treated cells (i.e., solvent control). After incubation, cells were harvested, and the total RNA was purified using Favor-Prep ${ }^{\mathrm{TM}}$ Blood/Cultured cell total RNA purification mini kit (Favorgen Biotech Corp., Ping-Tung, Taiwan). RNA was reverse transcribed into the first-strand cDNA using Revert Aid First Strand cDNA Synthesis Kit (Thermo Scientific, Waltham, MA, USA). HERA ${ }^{\text {PLUS }}$ SYBR $^{\circledR}$ Green qPCR Kit (Willowfort, Nottingham, UK) was utilized in quantitative polymerase chain reactions (qPCR). Gene expression was analyzed and quantified using the $2^{\wedge-\Delta \Delta C T}$ method [146]. The sequences of primers used are listed in Table S1.

\subsection{Western Blotting}

The expression of Bax, Bcl-2, Cyt-C, cleaved cas-3 and p53 proteins in Caco-2 cells was determined using Western blot procedure according to the methods mentioned previously $[147,148]$. In brief, $1 \times 10^{6}$ cells per well in 6-well plates in triplets were treated with the $\mathrm{IC}_{50}$ dose of ATRA, EC19 or EC23 for $24 \mathrm{~h}$. Then, cells were lysed in $150 \mu \mathrm{L}$ pre-cold lysis buffer [Tris-Base "10 mM", NaCl "100 mM", Ethylene glycol bis (2-aminoethyl) tetraacetic acid (EGTA) "20 mM", ethylenediaminetetraacetic acid (EDTA) " $25 \mathrm{mM}^{\prime}, 1 \%(v / v) \mathrm{NP}-40$, and $1 \%(v / v)$ Triton X-100; pH 7.4] immediately supplemented with 1:450 protease and phosphatase inhibitors cocktail (Sigma-Aldrich). Caco-2 cells were immediately collected by cell scraper, sonicated, and centrifuged at 12,000 rpm for $15 \mathrm{~min}$. Total proteins in the produced supernatant were determined colorimetrically using the Pierce ${ }^{\mathrm{TM}} 660 \mathrm{~nm}$ Assay (Thermo Scientific, Rockford, IL, USA). Equal amounts (30 $\mu \mathrm{g})$ of protein were mixed with sodium dodecyl sulfate (SDS)-loading buffer containing Tris-HCl, dithiothreitol (DTT), SDS, glycerol, and Bromophenol blue. The protein samples were then denatured by boiling for $5 \mathrm{~min}$, allowed to cool on ice for $10 \mathrm{~min}$ and separated by SDS-polyacrylamide gel electrophoresis (Cleaver Scientific Ltd., Rugby, Warwickshire, UK), and transferred onto Polyvinylidene Difluoride (PVDF) membranes for 30 min using Trans-Blot ${ }^{\circledR}$ SD semi-dry transfer cell (Biorad). Membranes were then blocked with 5\% (w/v) blotting-grade dry milk (Biorad) in Tris-buffered saline-Tween-20 (TBS-T), washed and incubated with antibodies against Bax, Bcl-2, cleaved caspase-3 (1:100-1:2000, Cell Signaling Technology), cytochrome c (1:500, Santa Cruz Biotechnology), p53 (1:1500, Abcam) and $\beta$-actin (1:2500, Sigma-Aldrich) for $16-17 \mathrm{~h}$ at $4{ }^{\circ} \mathrm{C}$ in a humidified chamber. The blots were washed, incubated at RT with matched horseradish peroxidase (HRP)-linked secondary antibodies (Dako, Denmark) for $1.5 \mathrm{~h}$, and the bands were visualized with chemiluminescence Western Lightning ECL (Perkin Elmer, Waltham, MA) for $1 \mathrm{~min}$ in Chemi-Doc imager (Biorad, Hercules, CA, USA) and finally analyzed with Bio-Rad Image Lab software with normalization to $\beta$-actin.

\subsection{Cell Invasion Assay}

Caco-2 cell invasion was assessed using a QCM ${ }^{\mathrm{TM}}$ 24-well Colorimetric Cell Invasion Assay kit (Chemicon International, Temecula, CA, USA (Cat \# ECM551)), according to 
the manufacturer's instructions. Cells were starved of serum for $24 \mathrm{~h}$. Then, cells were collected, suspended in serum-free Dulbecco's Modified Eagle Medium (DMEM) growth media containing either $\mathrm{IC}_{50}$ dose of retinoids or $0.1 \%$ DMSO (negative control), and seeded into the upper chamber of inserts at a density of $2.5 \times 10^{5}$ cells per insert and divided into two groups for either 24 or $48 \mathrm{~h}$. Inserts were further added into a 24-well plate containing $500 \mu \mathrm{L}$ of $10 \%$ FBS-containing DMEM per well. After incubation for 24 or $48 \mathrm{~h}$ at $37{ }^{\circ} \mathrm{C}$, remaining media was removed from the invasion chamber, and cells that had migrated to the other side of the membrane were stained with "Cell Stain" solution for 20 min at room temperature. Non-invaded cells were carefully removed from the upper side of the chamber with the help of cotton-tipped swabs. The stain of invaded cells was then extracted by $200 \mu \mathrm{L}$ of extraction buffer in a clean well for $15 \mathrm{~min}$ at room temperature. Finally, $100 \mu \mathrm{L}$ extracted stained solution was transferred into a 96-well plate and the optical density was measured at $490 \mathrm{~nm}$ with BioTek 800 TS microplate reader.

\subsection{Measurement of Intracellular and Secreted Glutamate}

The glutamate assay was performed using the Glutamate Assay Kit (Sigma-Aldrich, MAK004, St. Louis, MO, USA) according to the manufacturer's protocol [149]. In brief, $1 \times 10^{6}$ Caco-2 cells were seeded in 6-well plates in triplicates with 1-mL culture medium overnight and then treated with $\mathrm{IC}_{50}$ of retinoids in glutamate-free culture medium for $24 \mathrm{~h}$. Cells were lysed using $100 \mu \mathrm{L}$ glutamate assay buffer and insoluble cell debris was then removed by centrifugation at $13,000 \times g$ for $10 \mathrm{~min}$. The supernatant was transferred to a 10-KDa molecular weight cut-off (MWCO) spin filter (Sigma-Aldrich, St. Louis, MO, USA) to remove any particulates in the sample, and then was brought to a final volume of $50 \mu \mathrm{L}$ with glutamate assay buffer and transferred to a 96-well plate. Finally, $100 \mu \mathrm{L}$ of reaction mix was added to each well and the mixture was incubated for $30 \mathrm{~min}$ at $37^{\circ} \mathrm{C}$. The optical density was measured at $450 \mathrm{~nm}$ using BioTek $800 \mathrm{TS}$ microplate reader (BioTek, Winooski, VT, USA). For the measurement of secreted glutamate, $50 \mu \mathrm{L}$ samples of extracellular culture medium were placed in a 96-well plate and the kit's enzymatic reaction mix was added to induce a glutamate-dependent color change. After $30 \mathrm{~min}$ incubation, the reaction products were read at the same wavelength. For determination of glutamate concentration (nmole $/ \mu \mathrm{L}$ ), a calibration curve was constructed using supplied $0.1 \mathrm{M}$ glutamate standard with different dilutions (0 (blank), 2, 4, 6, 8 and 10 nmole per well). Glutamate concentration was measured according to the manufacturer's instruction and as documented in earlier studies [150-153].

\subsection{Total Antioxidant Capacity (TAC)}

Total antioxidant capacity was assayed spectrophotometrically using a Biodiagnostics ${ }^{\circledR}$ kit (Catalogue number TA 25 13, Biodiagnostics, Cairo, Egypt). Briefly, $1 \times 10^{6}$ Caco-2 cells per well were seeded in 6-well plates overnight, and then treated with the $\mathrm{IC}_{50}$ of retinoids for $24 \mathrm{~h}$. The measurement of total antioxidants is based on treating the cell lysate with a known excess of $\mathrm{H}_{2} \mathrm{O}_{2}(50 \mu \mathrm{M})$ [154]. A certain amount of $\mathrm{H}_{2} \mathrm{O}_{2}$, equivalent to TAC, is eliminated leaving a residual amount of $\mathrm{H}_{2} \mathrm{O}_{2}$ that is quantified colorimetrically by the enzymatic conversion of 3,5, dichloro-2-hydroxy benzene sulphonate to a colored product.

\subsection{Immunocytochemistry (ICC) and Detection of Morphological Changes}

Caco- 2 cells were seeded onto coverslips at a density of $1 \times 10^{6}$ cells using $0.1 \mathrm{mg} / \mathrm{mL}$ Poly-L-Lysine (Sigma-Aldrich, St. Louis, MO, USA) for immunocytochemistry (ICC) analysis. After treatment with $\mathrm{IC}_{50}$ of retinoids, cells were fixed in formalin neutral buffer (FNB) solution. The fixed cells were permeabilized with $0.1 \%$ Triton-x 100 and then blocked in $1 \%$ bovine serum albumin (BSA, prepared in PBS containing $0.1 \%$ Tween 20 ) for $30 \mathrm{~min}$. Then, cells were incubated with Alexa Fluor ${ }^{\circledR} 488$-conjugated anti-cytochrome C antibody overnight. After incubation, nuclei of cells were stained with Hoechst 33,258 (SigmaAldrich, St. Louis, MO, USA, 1:500). The coverslips were mounted in anti-fading medium (0.1\% p-phenylenediamine, dissolved in $90 \%$ glycerin/PBS) and cytochrome C protein 
expression was detected using Carl Zeiss LSM 710 confocal microscope. In addition, Caco-2 cell morphology was observed after treatment with $\mathrm{IC}_{50}$ for $24 \mathrm{~h}$ and representative images were captured by an inverted phase-contrast microscope (OPTECH Biostar IB) to detect the morphological changes.

\subsection{Statistical Analysis}

Statistical analysis was performed using GraphPad Prism 7 analysis software (GraphPad, San Diego, CA, USA). The significance of the data was analyzed using one-way analysis of variance (ANOVA). $p$ values of $p<0.05\left(^{*}\right), p<0.01\left({ }^{* *}\right)$, and $p<0.001\left(^{* * *}\right)$ were considered significant.

\section{Conclusions}

EC19 and EC23 are two novel synthetic derivatives of ATRA that inhibit the proliferation of multiple cancer cell lines. In Caco-2 cancer cells, EC19 was potent to induce cell cycle arrest at subG $\mathrm{G}_{0}-\mathrm{G}_{1}, \mathrm{~S}$ and $\mathrm{G}_{2} / \mathrm{M}$ phases. EC19 was able to re-express tumor suppressor genes (RAI2 and $W R N)$ and reduce the total cellular antioxidant capacity with more profound amplitudes than the parent ATRA compound. EC-synthetic retinoids have strong synergistic cytotoxicity in Caco-2 cells co-treated with 5-FU. However, additional in vitro and in vivo studies are needed to scrutinize the downstream pathways by which these retinoids, alone or in combination with standard chemotherapeutics, elicit their actions. Nonetheless, the present study suggests that EC-synthetic retinoids, and particularly EC19, may potentially be effective anticancer candidates for colorectal cancer. However, further in vivo investigations are required to confirm the anticancer activity and to discriminate between the two retinoid analogues in terms of biological potency.

Supplementary Materials: The following are available online, Figure S1. Dose-response curves for the antiproliferation assay showing the effects of EC19, EC23 and ATRA on the viability of different cancer and normal cell lines; Table S1. The sequences for primers used in quantitative real time PCR (qPCR) for gene expression analysis.

Author Contributions: Conceptualization, H.H., M.R.A., and S.H.S.; methodology, H.H., M.R.A., and M.R.E.; validation, M.R.A., H.H., and S.H.S.; formal analysis, M.R.A., M.R.E. and H.H.; investigation, M.R.A., H.H., and M.R.E.; resources, H.H., and S.H.S.; writing-original draft preparation, M.R.A., H.H., and M.R.E.; writing-review and editing, M.R.A., H.H., S.H.S., and M.R.E.; visualization, M.R.A., H.H., and M.R.E.; supervision, H.H. and S.H.S.; project administration, H.H.; funding acquisition, H.H. All authors have read and agreed to the published version of the manuscript.

Funding: This research work was funded by Egyptian Academy of Scientific Research and Technology (ASRT) under the grant call "National Program for Research and Innovation in Health and Biomedical Sciences" (ID: PRISM _ 5173), 2020-2022. SHS acknowledges the STDF grant (ID number 2950) for Center of Scientific Excellence "Helwan Structural Biology Research, (HSBR)".

Institutional Review Board Statement: Not applicable.

Informed Consent Statement: Not applicable.

Data Availability Statement: The data presented in this study are available in this article.

Conflicts of Interest: The authors declare no conflict of financial interest or personal relationships that could have influenced the work reported in this paper. The funders had no role in the design of the study, in the collection, analyses, or interpretation of data, or in the writing of the manuscript.

Sample Availability: Samples of the compounds are not available from the authors.

\section{References}

1. Das, B.C.; Thapa, P.; Karki, R.; Das, S.; Mahapatra, S.; Liu, T.C.; Torregroza, I.; Wallace, D.P.; Kambhampati, S.; Van Veldhuizen, P.; et al. Retinoic acid signaling pathways in development and diseases. Bioorg. Med. Chem. 2014, 22, 673-683. [CrossRef] [PubMed]

2. Marill, J.; Idres, N.; Capron, C.C.; Nguyen, E.; Chabot, G.G. Retinoic acid metabolism and mechanism of action: A review. Curr. Drug Metab. 2003, 4, 1-10. [PubMed] 
3. Soprano, D.R.; Harnish, D.C.; Soprano, K.J.; Kochhar, D.M.; Jiang, H. Correlations of RAR isoforms and cellular retinoid-binding proteins mRNA levels with retinoid-induced teratogenesis. J. Nutr. 1993, 123, 367-371. [CrossRef] [PubMed]

4. Nagpal, I.; Wei, L.-N. All-trans retinoic acid as a versatile cytosolic signal modulator mediated by CRABP1. Int. J. Mol. Sci. 2019, $20,3610-3620$.

5. Li, Y.; Wongsiriroj, N.; Blaner, W.S. The multifaceted nature of retinoid transport and metabolism. Hepatobiliary Surg. Nutr. 2014, 3, 126-139.

6. De Vos, S.; Koeffler, H.P. Differentiation Induction in Leukemia and Lymphoma. Nutritional Oncol. 2006, 491. [CrossRef]

7. Riahi, R.R.; Bush, A.E.; Cohen, P.R. Topical retinoids: Therapeutic mechanisms in the treatment of photodamaged skin. Am. J. Clin. Dermatol. 2016, 17, 265-276.

8. Kubilus, J.; Rand, R.; Baden, H.P. Effects of retinoic acid and other retinoids on the gowth and differentiation of $3 \mathrm{t} 3$ supported human keratinocytes. In Vitro 1981, 17, 786-795. [CrossRef]

9. Carratu, M.; Marasco, C.; Mangialardi, G.; Vacca, A. Retinoids: Novel immunomodulators and tumour-suppressive agents? Br. J. Pharmacol. 2012, 167, 483-492.

10. Cao, X. Retinoids Induced Cancer Stem Cell Differentiation and Apoptosis for Cancer Therapies. Mol. Cell Ther. 2019, 7, 1-8.

11. Abdel-Samad, R.; Aouad, P.; Darwiche, N. Natural and synthetic retinoids in preclinical colorectal cancer models. Anti-Cancer Drugs 2019, 30, 655-669. [CrossRef] [PubMed]

12. Lage, H. An overview of cancer multidrug resistance: A still unsolved problem. Cell Mol. Life Sci. 2008, 65, 3145-3167. [PubMed]

13. Wen, L.; Liang, C.; Chen, E.; Chen, W.; Liang, F.; Zhi, X.; Wei, T.; Xue, F.; Li, G.; Yang, Q.; et al. Regulation of Multi-drug Resistance in hepatocellular carcinoma cells is TRPC6/Calcium Dependent. Sci. Rep. 2016, 6, 1-14. [CrossRef] [PubMed]

14. Wilson, W.R.; Hay, M.P. Targeting hypoxia in cancer therapy. Nat. Rev. Cancer 2011, 11, 393-410.

15. Dobrotkova, V.; Chlapek, P.; Mazanek, P.; Sterba, J.; Veselska, R. Traffic lights for retinoids in oncology: Molecular markers of retinoid resistance and sensitivity and their use in the management of cancer differentiation therapy. BMC Cancer 2018, 18, 1059-1070. [CrossRef]

16. Muindi, J.; Frankel, S.R.; Miller, W.H., Jr.; Jakubowski, A.; Scheinberg, D.A.; Young, C.W.; Dmitrovsky, E.; Warrell, R.P., Jr. Continuous treatment with all-trans retinoic acid causes a progressive reduction in plasma drug concentrations: Implications for relapse and retinoid "resistance" in patients with acute promyelocytic leukemia. Blood 1992, 79, 299-303.

17. Muindi, J.R.; Frankel, S.R.; Huselton, C.; DeGrazia, F.; Garland, W.A.; Young, C.W.; Warrell, R.P., Jr. Clinical pharmacology of oral all-trans retinoic acid in patients with acute promyelocytic leukemia. Cancer Res. 1992, 52, 2138-2142.

18. Adedoyin, A.; Stiff, D.D.; Smith, D.C.; Romkes, M.; Bahnson, R.C.; Day, R.; Hofacker, J.; Branch, R.A.; Trump, D.L. All-transretinoic acid modulation of drug-metabolizing enzyme activities: Investigation with selective metabolic drug probes. Cancer Chemother. Pharmacol. 1998, 41, 133-139. [CrossRef]

19. Trump, D.L.; Smith, D.C.; Stiff, D.; Adedoyin, A.; Day, R.; Bahnson, R.R.; Hofacker, J.; Branch, R.A. A phase II trial of all-transretinoic acid in hormone-refractory prostate cancer: A clinical trial with detailed pharmacokinetic analysis. Cancer Chemother. Pharmacol. 1997, 39, 349-356.

20. Koskela, K.; Pelliniemi, T.T.; Pulkki, K.; Remes, K. Treatment of multiple myeloma with all-trans retinoic acid alone and in combination with chemotherapy: A phase I/II trial. Leuk. Lymphoma. 2004, 45, 749-754.

21. Gallagher, R.E. Retinoic acid resistance in acute promyelocytic leukemia. Leukemia 2002, 16, 1940-1958. [CrossRef] [PubMed]

22. Murayama, A.; Suzuki, T.; Matsui, M. Photoisomerization of retinoic acids in ethanol under room light: A warning for cell biological study of geometrical isomers of retinoids. J. Nutr. Sci. Vitaminol (Tokyo) 1997, 43, 167-176. [CrossRef] [PubMed]

23. Bempong, D.K.; Honigberg, I.L.; Meltzer, N.M. Normal phase LC-MS determination of retinoic acid degradation products. J. Pharm. Biomed. Anal. 1995, 13, 285-291. [CrossRef]

24. Han, G.; Chang, B.; Connor, M.J.; Sidell, N. Enhanced potency of 9-cis versus all-trans-retinoic acid to induce the differentiation of human neuroblastoma cells. Differentiation 1995, 59, 61-69. [CrossRef]

25. Lansink, M.; van Bennekum, A.M.; Blaner, W.S.; Kooistra, T. Differences in metabolism and isomerization of all-trans-retinoic acid and 9-cis-retinoic acid between human endothelial cells and hepatocytes. Eur. J. Biochem. 1997, 247, 596-604. [CrossRef]

26. Christie, V.B.; Barnard, J.H.; Batsanov, A.S.; Bridgens, C.E.; Cartmell, E.B.; Collings, J.C.; Maltman, D.J.; Redfern, C.P.F.; Marder, T.B.; Przyborski, S.; et al. Synthesis and evaluation of synthetic retinoid derivatives as inducers of stem cell differentiation. Org. Biomol. Chem. 2008, 6, 3497-3507. [CrossRef] [PubMed]

27. Haffez, H.; Khatib, T.; McCaffery, P.; Przyborski, S.; Redfern, C.; Whiting, A. Neurogenesis in response to synthetic retinoids at different temporal scales. Mol. Neurobiol. 2018, 55, 1942-1950. [CrossRef] [PubMed]

28. Haffez, H.; Chisholm, D.R.; Valentine, R.; Pohl, E.; Redfern, C.; Whiting, A. The molecular basis of the interactions between synthetic retinoic acid analogues and the retinoic acid receptors. Medchemcomm 2017, 8, 578-592. [CrossRef]

29. Christie, V.B.; Maltman, D.J.; Henderson, A.P.; Whiting, A.; Marder, T.B.; Lako, M.; Przyborski, S.A. Retinoid supplementation of differentiating human neural progenitors and embryonic stem cells leads to enhanced neurogenesis in vitro. J. Neurosci. Methods. 2010, 193, 239-245. [CrossRef]

30. Lopez-Real, R.; Budge, J.; Marder, T.; Whiting, A.; Hunt, P.; Przyborski, S.A. Application of synthetic photostable retinoids induces novel limb and facial phenotypes during chick embryogenesis in vivo. J. Anat. 2014, 224, 392-411. [CrossRef]

31. Sebaugh, J.; McCray, P. Defining the linear portion of a sigmoid-shaped curve: Bend points. Pharm. Stat. 2003, 2, 167-174. [CrossRef] 
32. Sebaugh, J. Guidelines for accurate EC50/IC50 estimation. Pharm. Stat. 2011, 10, 128-134. [CrossRef]

33. Koch, A.; Tamez, P.; Pezzuto, J.; Soejarto, D. Evaluation of plants used for antimalarial treatment by the Maasai of Kenya. J. Ethnopharmacol. 2005, 101, 95-99. [CrossRef] [PubMed]

34. Badisa, R.B.; Ayuk-Takem, L.T.; Ikediobi, C.O.; Walker, E.H. Selective Anticancer Activity of Pure Licamichauxiioic-B Acid in Cultured Cell Lines. Pharm. Biol. 2008, 44, 141-145. [CrossRef]

35. Rusdi, M.; Alam, G.; Manggau, M.A. Selective Cytotoxicity evaluation in Anticancer drug screening of Boehmeria virgata (Forst) Guill leaves to several human cell lines: HeLa, WiDr, T47D and Vero. Dhaka Univ. J. Pharm. Sci. 2013, 12, 87-90.

36. Vermes, I.; Haanen, C.; Reutelingsperger, C. Flow cytometry of apoptotic cell death. J. Immunol. Methods. 2000, 243, 167-190. [CrossRef]

37. Kalikaki, A.; Koutsopoulos, A.; Trypaki, M.; Souglakos, J.; Stathopoulos, E.; Georgoulias, V.; Mavroudis, D.; Voutsina, A. Comparison of EGFR and K-RAS gene status between primary tumours and corresponding metastases in NSCLC. Br. J. Cancer 2008, 99, 923-929. [CrossRef] [PubMed]

38. Jan, R. Understanding apoptosis and apoptotic pathways targeted cancer therapeutics. Adv. Pharm. Bull. 2019, 9, 205-218. [CrossRef] [PubMed]

39. Cai, J.; Yang, J.; Jones, D. Mitochondrial control of apoptosis: The role of cytochrome c. Biochim. Biophys. Acta Bioenerg. 1998, 1366, 139-149. [CrossRef]

40. Yan, W.; Wu, K.; Herman, J.G.; Xu, X.; Yang, Y.; Dai, G.; Guo, M. Retinoic acid-induced 2 (RAI2) is a novel tumor suppressor, and promoter region methylation of RAI2 is a poor prognostic marker in colorectal cancer. Clin. Epigenetics 2018, 10, 69-82. [CrossRef]

41. Lee, H.; Flaherty, P.; Ji, H.P. Systematic genomic identification of colorectal cancer genes delineating advanced from early clinical stage and metastasis. BMC Med. Genom. 2013, 6, 54-58. [CrossRef] [PubMed]

42. Agrelo, R.; Cheng, W.H.; Setien, F.; Ropero, S.; Espada, J.; Fraga, M.F.; Herranz, M.; Paz, M.F.; Sanchez-Cespedes, M.; Artiga, M.J.; et al. Epigenetic inactivation of the premature aging Werner syndrome gene in human cancer. Proc. Natl. Acad. Sci. USA 2006, 103, 8822-8827. [CrossRef] [PubMed]

43. Han, M.; Song, Y.; Zhang, X. Quercetin suppresses the migration and invasion in human colon cancer Caco-2 cells through regulating toll-like receptor 4/nuclear factor-kappa B pathway. Pharmacogn. Mag. 2016, 12, 237-244.

44. Su, J.; Liang, H.; Yao, W.; Wang, N.; Zhang, S.; Yan, X.; Feng, H.; Pang, W.; Wang, Y.; Wang, X.; et al. MiR-143 and MiR-145 regulate IGF1R to suppress cell proliferation in colorectal cancer. PLoS ONE 2014, 9, e114420. [CrossRef]

45. Basson, M.D.; Modlin, I.M.; Madri, J. Human enterocyte (Caco-2) migration is modulated in vitro by extracellular matrix composition and epidermal growth factor. J. Clin. Investig. 1992, 90, 15-23. [CrossRef]

46. Liu, Y.; Kong, X.; Li, H.; Shao, J.; Jiang, Z. SGK2 is overexpressed in colon cancer and promotes epithelial-mesenchymal transition in colon cancer cells. Eur. J. Surg. Oncol. 2020, 46, 1912-1917. [CrossRef]

47. Xu, J.; Zhou, J.; Dai, H.; Liu, F.; Li, W.; Wang, W.; Guo, F. CHIP functions as an oncogene by promoting colorectal cancer metastasis via activation of MAPK and AKT signaling and suppression of E-cadherin. J. Transl. Med. 2018, 16, 1-19. [CrossRef]

48. Huang, K.; Gao, N.; Bian, D.; Zhai, Q.; Yang, P.; Li, M.; Wang, X. Correlation between FAK and EGF-Induced EMT in Colorectal Cancer Cells. J. Oncol. 2020, 2020. [CrossRef]

49. Palchaudhuri, R.; Lambrecht, M.J.; Botham, R.C.; Partlow, K.C.; Van Ham, T.J.; Putt, K.S.; Nguyen, L.T.; Kim, S.-H.; Peterson, R.T.; Fan, T.M.; et al. A small molecule that induces intrinsic pathway apoptosis with unparalleled speed. Cell Rep. 2015, 13, 2027-2036. [CrossRef]

50. Heimer, S.; Knoll, G.; Schulze-Osthoff, K.; Ehrenschwender, M. Raptinal bypasses BAX, BAK, and BOK for mitochondrial outer membrane permeabilization and intrinsic apoptosis. Cell Death Dis. 2019, 10, 1-13. [CrossRef]

51. Khazaei, S.; Hamid, R.A.; Esa, N.M.; Ramachandran, V.; Aalam, G.T.F.; Etemad, A.; Ismail, P. Promotion of HepG2 cell apoptosis by flower of Allium atroviolaceum and the mechanism of action. BMC Complement. Altern. Med. 2017, 17, 104-116. [CrossRef] [PubMed]

52. Chao, X.; Wang, G.; Tang, Y.; Dong, C.; Li, H.; Wang, B.; Wu, J.; Zhao, J. The effects and mechanism of peiminine-induced apoptosis in human hepatocellular carcinoma HepG2 cells. PLoS ONE 2019, 14, e0201864. [CrossRef] [PubMed]

53. Kuwana, T.; King, L.E.; Cosentino, K.; Suess, J.; Garcia-Saez, A.J.; Gilmore, A.P.; Newmeyer, D.D. Mitochondrial residence of the apoptosis inducer BAX is more important than BAX oligomerization in promoting membrane permeabilization. J. Biol. Chem. 2020, 295, 1623-1636. [CrossRef]

54. Anderson, C.D.; Belous, A.; Pierce, J.; Nicoud, I.B.; Knox, C.; Wakata, A.; Pinson, C.W.; Chari, R.S. Mitochondrial calcium uptake regulates cold preservation-induced Bax translocation and early reperfusion apoptosis. Am. J. Transplant. 2004, 4, 352-362. [CrossRef] [PubMed]

55. Waterhouse, N.; Trapani, J. A new quantitative assay for cytochrome c release in apoptotic cells. Cell Death Differ. 2003, 10, 853-855. [CrossRef] [PubMed]

56. Shilkaitis, A.; Green, A.; Christov, K. Retinoids induce cellular senescence in breast cancer cells by RAR- $\beta$ dependent and independent pathways: Potential clinical implications. Int. J. Oncol. 2015, 47, 35-42. [CrossRef] [PubMed]

57. Qureshi-Baig, K.; Ullmann, P.; Haan, S.; Letellier, E. Tumor-Initiating Cells: A criTICal review of isolation approaches and new challenges in targeting strategies. Mol. Cancer 2017, 16, 40-55. [CrossRef]

58. Frankel, S.R.; Eardley, A.; Lauwers, G.; Weiss, M.; Warrell, R.P., Jr. The "retinoic acid syndrome" in acute promyelocytic leukemia. Ann. Intern. Med. 1992, 117, 292-296. [CrossRef] 
59. Palleria, C.; Di Paolo, A.; Giofrè, C.; Caglioti, C.; Leuzzi, G.; Siniscalchi, A.; De Sarro, G.; Gallelli, L. Pharmacokinetic drug-drug interaction and their implication in clinical management. J. Res. Med. Sci. 2013, 18, 601-610.

60. Vodenkova, S.; Buchler, T.; Cervena, K.; Veskrnova, V.; Vodicka, P.; Vymetalkova, V. 5-fluorouracil and other fluoropyrimidines in colorectal cancer: Past, present and future. Pharmacol. Ther. 2020, 206, 107447-107465. [CrossRef]

61. Blondy, S.; David, V.; Verdier, M.; Mathonnet, M.; Perraud, A.; Christou, N. 5-Fluorouracil resistance mechanisms in colorectal cancer: From classical pathways to promising processes. Cancer Sci. 2020, 111, 3142-3154. [CrossRef] [PubMed]

62. He, L.; Zhu, H.; Zhou, S.; Wu, T.; Wu, H.; Yang, H.; Mao, H.; SekharKathera, C.; Janardhan, A.; Edick, A.M.; et al. Wnt pathway is involved in 5-FU drug resistance of colorectal cancer cells. Exp. Mol. Med. 2018, 50, 1-12. [CrossRef] [PubMed]

63. Zhu, Y.-H.; Ye, N.; Tang, X.-F.; Khan, M.I.; Liu, H.-L.; Shi, N.; Hang, L.-F. Synergistic Effect of Retinoic Acid Polymeric Micelles and Prodrug for the Pharmacodynamic Evaluation of Tumor Suppression. Front. Pharmacol. 2019, 10, 447-457. [CrossRef] [PubMed]

64. Shougao, H.; Zhongsheng, X. Influences of ATRA and 5-FU on telomerase activity of gastric cancer cells and their antitumor effects. Zhongshan yi ke da xue xue bao= Zhongshan Yike Daxue Xuebao= Acad. J. Sun Yat-sen Univ. Med Sci. 2000, 21, 325-329.

65. Huang, R.-Y.; Pei, L.L.; Liu, Q.J.; Chen, S.Q.; Dou, H.B.; Shu, G.; Yuan, Z.-X.; Lin, J.C.; Peng, G.N.; Zhang, W.; et al. Isobologram Analysis: A Comprehensive Review of Methodology and Current Research. Front. Pharmacol. 2019, 10, 1222-1233. [CrossRef]

66. Schenk, T.; Stengel, S.; Zelent, A. Unlocking the potential of retinoic acid in anticancer therapy. Br. J. Cancer 2014, 111, 2039-2045. [CrossRef]

67. Szondy, Z.; Reichert, U.; Bernardon, J.-M.; Michel, S.; Tóth, R.; Ancian, P.; Ajzner, E.; Fesus, L. Induction of apoptosis by retinoids and retinoic acid receptor $\gamma$-selective compounds in mouse thymocytes through a novel apoptosis pathway. Mol. Pharmacol. 1997, 51, 972-982. [CrossRef]

68. Aggarwal, S.; Kim, S.-W.; Cheon, K.; Tabassam, F.H.; Yoon, J.-H.; Koo, J.S. Nonclassical action of retinoic acid on the activation of the cAMP response element-binding protein in normal human bronchial epithelial cells. Mol. Biol. Cell. 2006, 17, 566-575. [CrossRef]

69. Gluyas, J.B.; Burschka, C.; Dörrich, S.; Vallet, J.; Gronemeyer, H.; Tacke, R. Disila-analogues of the synthetic retinoids EC23 and TTNN: Synthesis, structure and biological evaluation. Org. Biomol. Chem. 2012, 10, 6914-6929. [CrossRef]

70. Nelson, A.M.; Gilliland, K.L.; Cong, Z.; Thiboutot, D.M. 13-cis Retinoic acid induces apoptosis and cell cycle arrest in human SEB-1 sebocytes. J. Investig. Dermatol. 2006, 126, 2178-2189. [CrossRef]

71. Zouboulis, C.C. Isotretinoin revisited: Pluripotent effects on human sebaceous gland cells. J. Investig. Dermatol. 2006, 126, 2154-2156. [CrossRef] [PubMed]

72. Fontana, J.; Rishi, A. Classical and novel retinoids: Their targets in cancer therapy. Leukemia 2002, 16, 463-472. [CrossRef] [PubMed]

73. Chen, Q.; Ross, A.C. Retinoic acid regulates cell cycle progression and cell differentiation in human monocytic THP-1 cells. Exp. Cell. Res. 2004, 297, 68-81. [CrossRef] [PubMed]

74. Liu, Y.; Wen, Q.; Chen, X.-L.; Yang, S.-J.; Gao, L.; Gao, L.; Zhang, C.; Li, J.-L.; Xiang, X.-X.; Wan, K.; et al. All-trans retinoic acid arrests cell cycle in leukemic bone marrow stromal cells by increasing intercellular communication through connexin 43-mediated gap junction. J. Hematol. Oncol. 2015, 8, 110-118. [CrossRef]

75. Hu, Z.; Long, T.; Ma, Y.; Zhu, J.; Gao, L.; Zhong, Y.; Wang, X.; Wang, X.; Li, Z. Downregulation of GLYR1 contributes to microsatellite instability colorectal cancer by targeting p21 via the p38MAPK and PI3K/AKT pathways. J. Exp. Clin. Cancer Res. 2020, 39, 1-15.

76. Gianni, M.; Ponzanelli, I.; Mologni, L.; Reichert, U.; Rambaldi, A.; Terao, M.; Garattini, E. Retinoid-dependent growth inhibition, differentiation and apoptosis in acute promyelocytic leukemia cells. Expression and activation of caspases. Cell Death Differ. 2000, 7, 447-460. [CrossRef]

77. Watabe, H.; Soma, Y.; Ito, M.; Kawa, Y.; Mizoguchi, M. All-trans retinoic acid induces differentiation and apoptosis of murine melanocyte precursors with induction of the microphthalmia-associated transcription factor. J. Investig. Dermatol. 2002, 118, 35-42. [CrossRef]

78. Bartolini, G.; Ammar, K.; Mantovani, B.; Scanabissi, F.; Ferreri, A.M.; Rocchi, P.; Orlandi, M. Retinoids and cancer: Antitumor effect of ATRA and of a new derivative of retinoic acid, IIF, on colon carcinoma cell lines CaCo-2 and HT-29. Anticancer Res. 2004, 24, 1779-1783.

79. McCormack, S.A.; Viar, M.J.; Tague, L.; Johnson, L.R. Altered distribution of the nuclear receptor RAR beta accompanies proliferation and differentiation changes caused by retinoic acid in Caco-2 cells. In Vitro Cell Dev. Biol. Anim. 1996, $32,53-61$. [CrossRef]

80. Spurling, C.C.; Suhl, J.A.; Boucher, N.; Nelson, C.E.; Rosenberg, D.W.; Giardina, C. The short chain fatty acid butyrate induces promoter demethylation and reactivation of RARbeta2 in colon cancer cells. Nutr. Cancer 2008, 60, 692-702. [CrossRef]

81. Imajo, M.; Kondoh, K.; Yamamoto, T.; Nakayama, K.; Nakajima-Koyama, M.; Nishida, E. Antagonistic interactions between extracellular signal-regulated kinase mitogen-activated protein kinase and retinoic acid receptor signaling in colorectal cancer cells. Mol. Cell Biol. 2017, 37. [CrossRef] [PubMed]

82. Lee, M.-O.; Han, S.-Y.; Jiang, S.; Park, J.H.; Kim, S.J. Differential effects of retinoic acid on growth and apoptosis in human colon cancer cell lines associated with the induction of retinoic acid receptor $\beta$. Biochem. Pharmacol. 2000, 59, 485-496. [CrossRef]

83. Chu, J.H.; Gao, Z.H.; Qu, X.J. Down-regulation of sphingosine kinase 2 (SphK2) increases the effects of all-trans-retinoic acid (ATRA) on colon cancer cells. Biomed. Pharmacother. 2014, 68, 1089-1097. [CrossRef] 
84. Gumireddy, K.; Sutton, L.N.; Phillips, P.C.; Reddy, C.D. All-trans-retinoic acid-induced apoptosis in human medulloblastoma: Activation of caspase-3/poly (ADP-ribose) polymerase 1 pathway. Clin. Cancer Res. 2003, 9, 4052-4059. [PubMed]

85. Hong, W.K.; Sporn, M.B. Recent advances in chemoprevention of cancer. Science 1997, 278, 1073-1077. [CrossRef] [PubMed]

86. Toma, S.; Raffo, P.; Isnardi, L.; Palumbo, R. Retinoids in lung cancer chemoprevention and treatment. Ann. Oncol. 1999, 10, 95-102. [CrossRef] [PubMed]

87. Wang, C.; Youle, R.J. The role of mitochondria in apoptosis. Annu. Rev. Genet. 2009, 43, 95-118. [CrossRef]

88. Haupt, S.; Berger, M.; Goldberg, Z.; Haupt, Y. Apoptosis-the p53 network. J. Cell Sci. 2003, 116, 4077-4085. [CrossRef]

89. Cohen, G.M. Caspases: The executioners of apoptosis. Biochem. J. 1997, 326, 1-16. [CrossRef]

90. Wang, R.-A.; Li, Z.-S.; Yan, Q.-G.; Bian, X.-W.; Ding, Y.-Q.; Du, X.; Sun, B.-C.; Sun, Y.-T.; Zhang, X.-H. Resistance to apoptosis should not be taken as a hallmark of cancer. Chin. J. Cancer. 2014, 33, 47-50. [CrossRef]

91. Hassan, M.; Watari, H.; AbuAlmaaty, A.; Ohba, Y.; Sakuragi, N. Apoptosis and molecular targeting therapy in cancer. Biomed. Res. Int. 2014, 2014. [CrossRef] [PubMed]

92. Jiang, H.; Zhao, P.J.; Su, D.; Feng, J.; Ma, S.L. Paris saponin I induces apoptosis via increasing the Bax/Bcl-2 ratio and caspase-3 expression in gefitinib-resistant non-small cell lung cancer in vitro and in vivo. Mol. Med. Rep. 2014, 9, 2265-2272. [CrossRef] [PubMed]

93. Gazzaniga, P.; Gradilone, A.; Vercillo, R.; Gandini, O.; Silvestri, I.; Napolitano, M.; Albonici, L.; Vincenzoni, A.; Gallucci, M.; Frati, L.; et al. bcl-2/bax mRNA expression ratio as prognostic factor in low-grade urinary bladder cancer. Int. J. Cancer 1996, 69, 100-104. [CrossRef]

94. Shimizu, S.; Narita, M.; Tsujimoto, Y. Bcl-2 family proteins regulate the release of apoptogenic cytochrome $\mathrm{c}$ by the mitochondrial channel VDAC. Nature 1999, 399, 483-487. [CrossRef]

95. McIlwain, D.R.; Berger, T.; Mak, T.W. Caspase functions in cell death and disease. Cold Spring Harb. Perspect. Biol. 2015, 7. [CrossRef]

96. Vogel, C.; Marcotte, E.M. Insights into the regulation of protein abundance from proteomic and transcriptomic analyses. Nat. Rev. Genet. 2012, 13, 227-232. [CrossRef]

97. Maximov, G.; Maximov, K. The role of p53 tumor-suppressor protein in apoptosis and cancerogenesis. Biotechnol. Biotechnol. Equip. 2008, 22, 664-668. [CrossRef]

98. Fridman, J.S.; Lowe, S.W. Control of apoptosis by p53. Oncogene 2003, 22, 9030-9040. [CrossRef]

99. Sexton, R.E.; Hachem, A.H.; Assi, A.A.; Bukhsh, M.A.; Gorski, D.H.; Speyer, C.L. Metabotropic glutamate receptor-1 regulates inflammation in triple negative breast cancer. Sci. Rep. 2018, 8, 1-11. [CrossRef]

100. Luo, W.Y.; Xing, S.Q.; Zhu, P.; Zhang, C.G.; Yang, H.M.; Van Halm-Lutterodt, N.; Gu, L.; Zhang, H. PDZ Scaffold Protein CAL Couples with Metabotropic Glutamate Receptor 5 to Protect Against Cell Apoptosis and Is a Potential Target in the Treatment of Parkinson's Disease. Neurotherapeutics 2019, 16, 761-783. [CrossRef]

101. Stepulak, A.; Rola, R.; Polberg, K.; Ikonomidou, C. Glutamate and its receptors in cancer. J. Neural. Transm. (Vienna) 2014, 121, 933-944. [CrossRef] [PubMed]

102. Khan, A.J.; LaCava, S.; Mehta, M.; Schiff, D.; Thandoni, A.; Jhawar, S.; Danish, S.; Haffty, B.G.; Chen, S. The glutamate release inhibitor riluzole increases DNA damage and enhances cytotoxicity in human glioma cells, in vitro and in vivo. Oncotarget 2019, 10, 2824-2834. [CrossRef] [PubMed]

103. Yu, D.; Shi, X.; Meng, G.; Chen, J.; Yan, C.; Jiang, Y.; Wei, J.; Ding, Y. Kidney-type glutaminase (GLS1) is a biomarker for pathologic diagnosis and prognosis of hepatocellular carcinoma. Oncotarget 2015, 6, 7619-7631. [CrossRef] [PubMed]

104. Choi, Y.-K.; Park, K.-G. Targeting glutamine metabolism for cancer treatment. Biomol. Ther. 2018, 26, 19-28. [CrossRef]

105. Alberghina, L.; Gaglio, D. Redox control of glutamine utilization in cancer. Cell Death Dis. 2014, 5, e1561. [CrossRef]

106. Altman, B.J.; Stine, Z.E.; Dang, C.V. From Krebs to clinic: Glutamine metabolism to cancer therapy. Nat. Rev. Cancer. 2016, 16, 619-634. [CrossRef]

107. Matés, J.M.; Campos-Sandoval, J.A.; Santos-Jiménez, J.L.; Márquez, J. Dysregulation of glutaminase and glutamine synthetase in cancer. Cancer Lett. 2019, 467, 29-39. [CrossRef]

108. Katt, W.P.; Cerione, R.A. Glutaminase regulation in cancer cells: A druggable chain of events. Drug Discov. Today 2014, 19, 450-457. [CrossRef]

109. Budczies, J.; Pfitzner, B.M.; Györffy, B.; Winzer, K.J.; Radke, C.; Dietel, M.; Fiehn, O.; Denkert, C. Glutamate enrichment as new diagnostic opportunity in breast cancer. Int. J. Cancer 2015, 136, 1619-1628. [CrossRef]

110. Willard, S.S.; Koochekpour, S. Glutamate signaling in benign and malignant disorders: Current status, future perspectives, and therapeutic implications. Int. J. Biol. Sci. 2013, 9, 728-742. [CrossRef]

111. Tudek, B.; Speina, E. Oxidatively damaged DNA and its repair in colon carcinogenesis. Mutat. Res. 2012, 736, 82-92. [CrossRef] [PubMed]

112. Han, C.; Wang, Z.; Xu, Y.; Chen, S.; Han, Y.; Li, L.; Wang, M.; Jin, X. Roles of Reactive Oxygen Species in Biological Behaviors of Prostate Cancer. Biomed. Res. Int. 2020, 2020. [CrossRef]

113. Sedlak, T.W.; Paul, B.D.; Parker, G.M.; Hester, L.D.; Snowman, A.M.; Taniguchi, Y.; Kamiya, A.; Snyder, S.H.; Sawa, A. The glutathione cycle shapes synaptic glutamate activity. Proc. Natl. Acad. Sci. USA 2019, 116, 2701-2706. [CrossRef] [PubMed]

114. Lu, S.C. Regulation of glutathione synthesis. Mol. Asp. Med. 2009, 30, 42-59. [CrossRef] 
115. Kumar, J.; Liddle, E.B.; Fernandes, C.C.; Palaniyappan, L.; Hall, E.L.; Robson, S.E.; Simmonite, M.; Fiesal, J.; Katshu, M.Z.; Qureshi, A.; et al. Glutathione and glutamate in schizophrenia: A 7T MRS study. Mol. Psychiatry 2018, 25, 1-10. [CrossRef] [PubMed]

116. van Zijl, F.; Krupitza, G.; Mikulits, W. Initial steps of metastasis: Cell invasion and endothelial transmigration. Mutat. Res. 2011, 728, 23-34. [CrossRef]

117. Edward, M. Effect of retinoids on tumour invasion and metastasis. Pathobiology 1992, 60, 271-277. [CrossRef]

118. Park, E.Y.; Wilder, E.T.; Lane, M.A. Retinol Inhibits the Invasion of Retinoic Acid-Resistant Colon Cancer Cells In Vitro and Decreases Matrix Metalloproteinase MRNA, Protein, and Activity Levels. Nutr. Cancer 2007, 57, 66-77. [CrossRef]

119. Sun, J.; Lu, Z.; Deng, Y.; Wang, W.; He, Q.; Yan, W.; Wang, A. Up-regulation of INSR/IGF1R by C-myc promotes TSCC tumorigenesis and metastasis through the NF-kB pathway. Biochim. Biophys. Acta Mol. Basis Dis. 2018, 1864, 1873-1882. [CrossRef]

120. Wang, S.-Q.; Yang, X.-Y.; Yu, X.-F.; Cui, S.-X.; Qu, X.-J. Knockdown of IGF-1R triggers viral RNA sensor MDA5-and RIG-I-mediated mitochondrial apoptosis in colonic cancer cells. Mol. Ther. Nucleic Acids. 2019, 16, 105-117. [CrossRef]

121. Cui, J.; Gong, M.; He, Y.; Li, Q.; He, T.; Bi, Y. All-trans retinoic acid inhibits proliferation, migration, invasion and induces differentiation of hepa1-6 cells through reversing EMT in vitro. Int. J. Oncol. 2015, 48, 349-357. [CrossRef] [PubMed]

122. Kuczynski, E.A.; Viloria-Petit, A.M.; Coomber, B.L. Colorectal carcinoma cell production of transforming growth factor beta decreases expression of endothelial cell vascular endothelial growth factor receptor 2. Cancer 2011, 117, 5601-5611. [CrossRef] [PubMed]

123. Massagué, J.; Gomis, R.R. The logic of TGF $\beta$ signaling. FEBS Lett. 2006, 580, 2811-2820.

124. Levy, L.; Hill, C.S. Alterations in components of the TGF- $\beta$ superfamily signaling pathways in human cancer. Cytokine Growth Factor Rev. 2006, 17, 41-58. [CrossRef]

125. Daulagala, A.C.; Bridges, M.C.; Kourtidis, A. E-cadherin Beyond Structure: A Signaling Hub in Colon Homeostasis and Disease. Int. J. Mol. Sci. 2019, 20, 2756. [CrossRef]

126. El-Bahrawy, M.; Poulsom, S.R.; Rowan, A.J.; Tomlinson, I.T.; Alison, M.R. Characterization of the E-cadherin/catenin complex in colorectal carcinoma cell lines. Int. J. Exp. Pathol. 2004, 85, 65-74. [CrossRef]

127. Werner, S.; Brors, B.; Eick, J.; Marques, E.; Pogenberg, V.; Parret, A.; Kemming, D.; Wood, A.W.; Edgren, H.; Neubauer, H.; et al. Suppression of early hematogenous dissemination of human breast cancer cells to bone marrow by retinoic Acid-induced 2. Cancer Discov. 2015, 5, 506-519. [CrossRef]

128. Esposito, M.; Kang, Y. RAI2: Linking retinoic acid signaling with metastasis suppression. Cancer Discov. 2015, 5, 466-468. [CrossRef]

129. Hickson, I.D. RecQ helicases: Caretakers of the genome. Nat. Rev. Cancer 2003, 3, 169-178. [CrossRef]

130. Yamamoto, K.; Imakiire, A.; Miyagawa, N.; Kasahara, T. A report of two cases of Werner's syndrome and review of the literature. J. Orthop. Surg. (Hong Kong) 2003, 11, 224-233. [CrossRef]

131. Smith, J.A.; Ndoye, A.M.; Geary, K.; Lisanti, M.P.; Igoucheva, O.; Daniel, R. A role for the Werner syndrome protein in epigenetic inactivation of the pluripotency factor Oct4. Aging Cell. 2010, 9, 580-591. [CrossRef] [PubMed]

132. Blander, G.; Kipnis, J.; Leal, J.F.; Yu, C.E.; Schellenberg, G.D.; Oren, M. Physical and functional interaction between p53 and the Werner's syndrome protein. J. Biol. Chem. 1999, 274, 29463-29469. [CrossRef] [PubMed]

133. Haffez, H.; Taha, H.; Rabie, M.A.; Awad, S.M.; Zohny, Y.M. Synthesis, Biological Evaluation and Molecular Docking Studies of Novel Thiopyrimidine Analogue as Apoptotic Agent with Potential Anticancer Activity. Bioorg. Chem. 2020, $104,104249$. [CrossRef] [PubMed]

134. Peña-Morán, O.A.; Villarreal, M.L.; Álvarez-Berber, L.; Meneses-Acosta, A.; Rodríguez-López, V. Cytotoxicity, post-treatment recovery, and selectivity analysis of naturally occurring podophyllotoxins from Bursera fagaroides var. fagaroides on breast cancer cell lines. Molecules 2016, 21, 1013. [CrossRef]

135. Braga, C.B.; Kido, L.A.; Lima, E.N.; Lamas, C.A.; Cagnon, V.r.H.; Ornelas, C.; Pilli, R.A. Enhancing the Anticancer Activity and Selectivity of Goniothalamin Using pH-Sensitive Acetalated Dextran (Ac-Dex) Nanoparticles: A Promising Platform for Delivery of Natural Compounds. ACS Biomater. Sci. Eng. 2020, 6, 2929-2942. [CrossRef]

136. Ye, L.; Tao, K.; Yu, Y.; Wang, G. Reduction of G0 phase cells of colon cancer caco-2 cells may enhance 5-fluorouracil efficacy. J. Biomed. Res. 2010, 24, 64-68. [CrossRef]

137. Handali, S.; Moghimipour, E.; Rezaei, M.; Ramezani, Z.; Kouchak, M.; Amini, M.; Angali, K.A.; Saremy, S.; Dorkoosh, F.A. A novel 5-Fluorouracil targeted delivery to colon cancer using folic acid conjugated liposomes. Biomed. Pharmacother. 2018, 108, 1259-1273. [CrossRef]

138. Chou, T.C.; Talalay, P. Generalized equations for the analysis of inhibitions of Michaelis-Menten and higher-order kinetic systems with two or more mutually exclusive and nonexclusive inhibitors. Eur. J. Biochem. 1981, 115, 207-216. [CrossRef]

139. Chou, T.C.; Talalay, P. Quantitative analysis of dose-effect relationships: The combined effects of multiple drugs or enzyme inhibitors. Adv. Enzyme Regul. 1984, 22, 27-55. [CrossRef]

140. Huang, L.; Jiang, Y.; Chen, Y. Predicting drug combination index and simulating the network-regulation dynamics by mathematical modeling of drug-targeted EGFR-ERK signaling pathway. Sci. Rep. 2017, 7, 40752-40760. [CrossRef] [PubMed]

141. Wali, V.B.; Sylvester, P.W. Synergistic antiproliferative effects of gamma-tocotrienol and statin treatment on mammary tumor cells. Lipids 2007, 42, 1113-1123. [CrossRef] [PubMed]

142. Erdem, S.S.; Obeidin, V.A.; Yigitbasi, T.; Tumer, S.S.; Yigit, P. Verteporfin mediated sequence dependent combination therapy against ovarian cancer cell line. J. Photochem. Photobiol. B. 2018, 183, 266-274. [CrossRef] [PubMed] 
143. Ji, Y.; Yu, M.; Qi, Z.; Cui, D.; Xin, G.; Wang, B.; Jia, W.; Chang, L. Study on apoptosis effect of human breast cancer cell MCF-7 induced by lycorine hydrochloride via death receptor pathway. Saudi Pharm. J. 2017, 25, 633-637. [CrossRef] [PubMed]

144. Merchant, S.H.; Gonchoroff, N.J.; Hutchison, R.E. Apoptotic index by Annexin V flow cytometry: Adjunct to morphologic and cytogenetic diagnosis of myelodysplastic syndromes. Cytometry 2001, 46, 28-32. [CrossRef]

145. Potten, C.S. What is an apoptotic index measuring? A commentary. Br. J. Cancer 1996, 74, 1743-1748. [CrossRef]

146. Livak, K.J.; Schmittgen, T.D. Analysis of relative gene expression data using real-time quantitative PCR and the 2(-Delta Delta C(T)) Method. Methods 2001, 25, 402-408. [CrossRef]

147. Burnette, W.N. "Western Blotting": Electrophoretic transfer of proteins from sodium dodecyl sulfate-polyacrylamide gels to unmodified nitrocellulose and radiographic detection with antibody and radioiodinated protein A. Anal. Biochem. 1981, 112, 195-203. [CrossRef]

148. Sambrook, H. Molecular Cloning: A Laboratory Manual; Cold Spring Harb.: Plainview, NY, USA, 1989.

149. Fazzari, J.; Lin, H.; Murphy, C.; Ungard, R.; Singh, G. Inhibitors of glutamate release from breast cancer cells; new targets for cancer-induced bone-pain. Sci. Rep. 2015, 5, 8380-8386. [CrossRef]

150. Zhang, Z.; Liu, J.; Fan, C.; Mao, L.; Xie, R.; Wang, S.; Yang, M.; Yuan, H.; Yang, X.; Sun, J.; et al. The GluN1/GluN2B NMDA receptor and metabotropic glutamate receptor 1 negative allosteric modulator has enhanced neuroprotection in a rat subarachnoid hemorrhage model. Exp. Neurol. 2018, 301, 13-25. [CrossRef]

151. Zhu, C.; Xu, Q.; Wang, C.; Mao, Z.; Lin, N. Evidence that CA3 is underling the comorbidity between pain and depression and the co-curation by Wu-Tou decoction in neuropathic pain. Sci. Rep. 2017, 7, 1-14. [CrossRef]

152. Mishra, P.-S.; Vijayalakshmi, K.; Nalini, A.; Sathyaprabha, T.; Kramer, B.; Alladi, P.A.; Raju, T. Etiogenic factors present in the cerebrospinal fluid from amyotrophic lateral sclerosis patients induce predominantly pro-inflammatory responses in microglia. $J$. Neuroinflamm. 2017, 14, 1-18. [CrossRef] [PubMed]

153. Polletta, L.; Vernucci, E.; Carnevale, I.; Arcangeli, T.; Rotili, D.; Palmerio, S.; Steegborn, C.; Nowak, T.; Schutkowski, M.; Pellegrini, L.; et al. SIRT5 regulation of ammonia-induced autophagy and mitophagy. Autophagy 2015, 11, 253-270. [CrossRef] [PubMed]

154. Koracevic, D.; Koracevic, G.; Djordjevic, V.; Andrejevic, S.; Cosic, V. Method for the measurement of antioxidant activity in human fluids. J. Clin. Pathol. 2001, 54, 356-361. [CrossRef] [PubMed] 